\title{
Tectonics of the Lepontine Alps: ductile thrusting and folding in the deepest tectonic levels of the Central Alps
}

\author{
Albrecht Steck • Franco Della Torre • Franz Keller • \\ Hans-Rudolf Pfeifer · Johannes Hunziker · Henri Masson
}

Received: 9 October 2012/ Accepted: 29 May 2013/Published online: 17 July 2013

(C) Swiss Geological Society 2013

\begin{abstract}
The Lepontine dome represents a unique region in the arc of the Central and Western Alps, where complex fold structures of upper amphibolite facies grade of the deepest stage of the orogenic belt are exposed in a tectonic half-window. The NW-verging Mont Blanc, Aar und Gotthard basement folds and the Lower Penninic gneiss nappes of the Central Alps were formed by ductile detachment of the upper European crust during its Late Eocene-Early Oligocene SE-directed underthrust below the upper Penninic and Austroalpine thrusts and the Adriatic plate. Four underthrust zones are distinguished in the NW-verging stack of Alpine fold nappes and thrusts: the Canavese, Piemont, Valais and Adula zones. Up to three schistosities S1-S3, folds F1-F3 and a stretching lineation XI with top-to-NW shear indicators were developed in the F1-F3 fold nappes. Spectacular F4 transverse folds, the SW-verging Verzasca, Maggia, Ziccher, Alpe Bosa and Wandfluhhorn anticlines and synclines overprint the Alpine nappe stack. Their formation under amphibolite facies grade was related to late ductile folding of the southern nappe roots during dextral displacement of the
\end{abstract}

Editorial handling: A. G. Milnes.

Electronic supplementary material The online version of this article (doi:10.1007/s00015-013-0135-7) contains supplementary material, which is available to authorized users.

A. Steck $(\bowtie) \cdot$ H.-R. Pfeifer · J. Hunziker · H. Masson Institut des Sciences de la Terre, Université de Lausanne, bâtiment Geopolis, Dorigny, 1015 Lausanne, Switzerland e-mail: Albrecht.Steck@unil.ch

F. Della Torre

Dr. P. Ammann SA, 6616 Losone, Switzerland

F. Keller

Lüssirain 59, 6300 Zug, Switzerland
Adriatic indenter. The transverse folding F4 was followed since 30 Ma by the pull-apart exhumation and erosion of the Lepontine dome. This occurred coevally with the formation of the dextral ductile Simplon shear zone, the S-verging backfolding F5 and the formation of the southern steep belt. Exhumation continued after $18 \mathrm{Ma}$ with movement on the brittle Rhone-Simplon detachment, accompanied by the N-, NW- and W-directed Helvetic and Dauphiné thrusts. The dextral shear is dated by the 29-25 Ma crustal-derived aplite and pegmatite intrusions in the southern steep belt. The cooling by uplift and erosion of the Tertiary migmatites of the Bellinzona region occurred between 22 and 18 Ma followed by the exhumation of the Toce dome on the brittle RhoneSimplon fault since $18 \mathrm{Ma}$.

Keywords Switzerland · Italy · Alpine orogeny · Tertiary fold structures · Gneiss dome - Geochronology

\section{Introduction}

The Lepontine gneiss dome of the Central Alps represents an exceptional outcrop of a collisional mountain belt. The Lepontine dome is defined by the area of Tertiary amphibolite facies metamorphism and consists of basement nappes separated by their Mesozoic cover series of the deepest tectonic level of the Central Alpine structural culmination (Fig. 1). This dome structure is unique in the Western and Central Alpine arc. Another dome structure with an amphibolite facies gneiss core is exposed in the Tauern window of the Eastern Alps (e.g. Schmid et al. 2004). In the Lepontine dome the transition from the more simple thrust structures of the high tectonic lid to the deepest tectonic amphibolite facies units with their ductile fold structures can be studied in continuous profiles. Complex fold interference structures are exposed in a tectonic half-window 


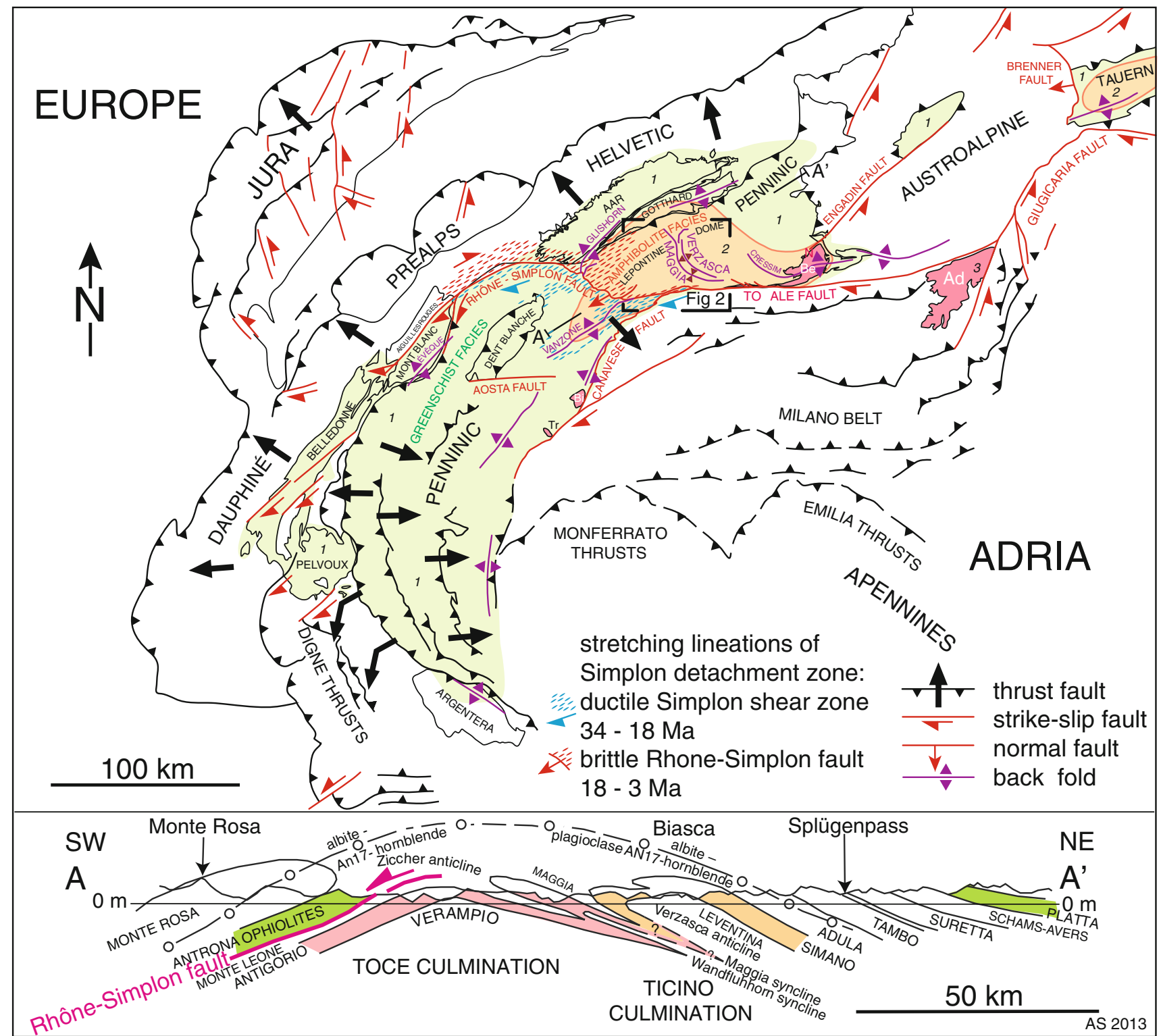

Fig. 1 Oligocene and Neogene structures and metamorphism of the Central and Western Alps, modified after Frey et al. (1999), Steck et al. (2001) and Oberhänsli (2004) showing the location of the structural map of the central Lepontine Alps (Fig. 2) and the cross-section A-A' (see also Fig. 8). The zones of the Late Cretaceous and Eocene high-pressure metamorphism are not represented. It is suggested that the anchizonegreenschist facies limit, corresponding to a temperature of about $300{ }^{\circ} \mathrm{C}$ represents an important rheological boundary in the quartz-rich granitic European crust that controls the position of the frontal NW verging and en echelon Belledonne, Mont Blanc and Aar F2 basement folds in the zone of NW-SE directed Alpine compression between the European and Adriatic plates. The greenschist-amphibolite facies boundary which delimits the Lepontine dome is defined by the reaction: albite An

of the deeply eroded gneiss dome located between the Toce and Ticino rivers, limited to the south by the Canavese and Tonale faults of the Insubric line.

The aims of this paper are (1) to describe and decipher the geometry of the structures of the Lepontine Alps and
$0-3+$ epidote + hornblende $=$ oligoclas $\quad$ An $>17+$ hornblende (Wenk and Keller 1969; Steck 2008). The Adamello gabbros, diorites and granites (Ad), 32-29 Ma Bergell tonalites and granites (Be), 31-30 Ma Biella pluton (Bi) and Traversella diorite ( $\mathrm{Tr}$ ) are Oligocene mantle-derived intrusions located along the Insubric line, the limit between the European and Adriatic plates (Beccaluva et al. 1983; Reusser 1987; Romer et al. 1996; Berger et al. 2012; Kapferer et al. 2012). The dextral Rhône-Simplon fault continues to the west in the Chamonix zone and after new observations by Daniel Egli (personnel communication) also along the Penninic front to the east of the Mont Blanc massif. (1) Oligocene-Miocene greenschist facies metamorphism, (2) Oligocene-Miocene amphibolite facies metamorphism, (3) Mantle derived dioritic magmatism

(2) to discuss a revised tectonic and kinematic model in the light of recent field investigations, together with a compilation of structural data collected by the authors. The classic geological documents of the early twenty century (Preiswerk et al. 1934; Niggli et al. 1936; Wenk 1955) have 
been completed with detailed geological maps at a scale of 1:25,000, i.e. Campo Tencia (Keller et al. 1980), Bellinzona (Baechlin et al. 1974) and Valli Vigezzo, Fenecchio e Basso Isorno (Bigioggero et al. 1981a, b), and numerous Ph.D. theses (Burckhardt 1942; Hasler 1949; Kobe 1956; Knup 1958; Hunziker 1966; Reinhardt 1966; Wieland 1966; Keller 1968; Bianconi 1971; Colombi 1989; Brouwer et al. 2005; Burri 2005). In addition, the tectonic models by Merle et al. (1989), Grujic and Mancktelow (1996), Maxelon and Mancktelow (2005), Berger et al. (2005), Berger and Mercolli (2006), Galli et al. (2007) and Steck $(1998,2008)$ have been considered. The 1:25,000 map sheets Bosco Gurin (by Franco Della Torre and Luca Maggini), Maggia (by Paul Gräter $(\dagger)$, Eduard Wenk $(\dagger)$ and Thomas Burri) and Locarno (by Alberto Colombi, Peter Knup, Huldrich Kobe and Hans-Rudolf Pfeifer) have been submitted for publication in the Swiss geological atlas and are available as provisional editions.

The progress of geological knowledge has been enormous since the classical descriptions of Niggli et al. (1936), but important questions concerning the complexity of the observed structures are still debated. Chatterjee (1961) postulate that the formation of the Simplon nappe stack by brittle thrusting was followed by heating, orogenic metamorphism and folding. Milnes (1975) (in response to Streckeisen et al. 1974) considered steep and overturned metamorphic isograds of the Simplon tunnel transect as evidence for synmetamorphic ductile folding and NWdirected thrusting. The post-nappe folding in the adjacent Lepontine gneiss dome was recognised by Milnes (1974), Milnes et al. (1981), Huber et al. (1980), Huber (1981), Steck (1984, 2008), Merle et al. (1989), Grujic and Mancktelow (1996) and Maxelon and Mancktelow (2005).

In this paper, we present a synthesis of all these data on the complexity of the post-nappe folding in the Lepontine dome in the form of a new tectonic map (Fig. 2, printed here as a fold-out at the back of this issue of SJG), accompanied by a series of structural cross-sections through the dome (Fig. 3). The following Sect. 2 presents in detail the Lower Penninic tectonic units within the Lepontine dome. Section 3 gives only a brief description of the Tectonic units surrounding the Lepontine dome (Middle-Upper Penninic, Austroalpine and South Alpine). The Alpine structures and metamorphism of the Lepontine dome are described in Sect. 4. The complex structural evolution of the Lepontine dome is discussed in the final Sect. 5.

\section{Tectonic units within the Lepontine dome (Lower Penninic)}

The studied area is composed of a NW-verging stack of basement and post-Carboniferous cover nappes. From north to south these are: (1) the Helvetic Aar and Gotthard folds, (2) the Lower Penninic units detached from the upper European crust, (3) the Valais basin calc-schists, (4) the Middle Penninic units attributed to the Briançonnais domain, (5) the Upper Penninic Antrona and Zermatt-Saas oceanic crust elements of the Piemont ocean, (6) the Sesia zone of the Austroalpine domain and (7) the Southern Alps forming the northern margin of the Adriatic plate. As indicated in Table 1, four deep underthrust zones are distinguished in the Central Alps: (a) the Adula underthrust of the Lower Penninic (European) domain contains the eclogitic Mergoscia and Cima Lunga units and the amphibolite facies BoscoBombogno-Isorno-Orselina Zone, (b) the Valais units and Viège (Visp) Mélange mark the Valais underthrust at the limit of the Lower Penninic (European) and Middle Penninic (Briançonnais) domains, (c) the eclogitic Upper Penninic Antrona and Zermatt-Saas zones are exposed in the Piemont underthrust at the limit of the Penninic and Austroalpine domains and (d) the Canavese underthrust represents the limit between the Austroalpine Sesia zone with its late Cretaceous high-pressure metamorphism and the Southern Alps, the north-western margin of the Adriatic plate.

Most units of the Helvetic, Penninic, Austroalpine and South Alpine domains are composed of polycyclic Caledonian and Variscan basement gneisses that are overlain by Permian, Mesozoic and Cenozoic sediments. The Upper Penninic Antrona and Zermatt-Saas zones are composed of Piemont oceanic crust of Middle to Late Jurassic age. The regional distribution of the different tectonic units is indicated on a paleogeographic map of the Alpine Tethys at the Santonian some $84 \mathrm{Ma}$ ago before the Late Cretaceous and Tertiary convergence of the European and Adriatic plates (Fig. 4). The different tectonic units within the Lepontine dome, as distinguished in Table 1 and Fig. 4, are described briefly below.

\subsection{The Lower Penninic units of the European domain}

\subsubsection{The Verampio unit}

The Verampio and Leventina units are the deepest units of the Alpine nappe stack, exposed in the Toce and Ticino dome structures (Figs. 2, 3; Table 1). The deep seismic study (Swiss National Foundation Project no. 20, Steck et al. 1997; Steck 2008) confirmed the thrust sheet geometry of the Verampio nappe, itself separated by an unnamed nappe (X-nappe on cross-section 3, Fig. 3) from the root of the northern Gotthard fold nappe. The Verampio fold nappe is composed of the $291 \pm 4$ Ma old Verampio granite (U-Pb zircon age, François Bussy in Steck et al. 2001) intrusive in Paleozoic meta-greywackes (Baceno schists) and separated from the higher Antigorio fold nappe by a syncline of autochthonous Mesozoic sediments, the Teggiolo zone (Steck et al. 1999, 2001). 


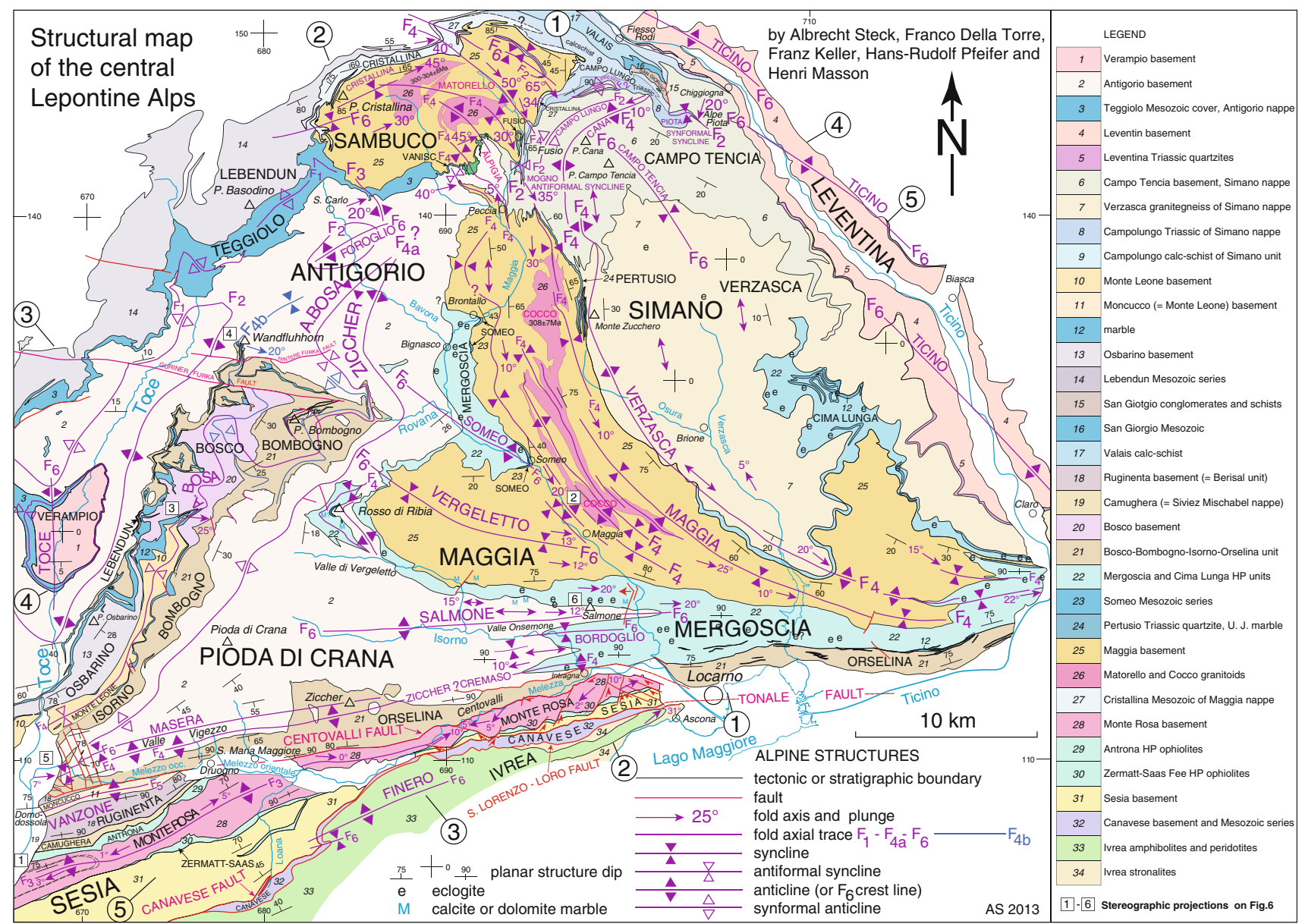

Fig. 2 Structural map of the Lepontine Alps after field observations by Preiswerk et al. (1934), Hasler (1949), Kobe (1956), Knup (1958), Hunziker (1966), Wieland (1966), Keller (1968), Bianconi (1971), Keller et al. (1980), Colombi (1989), Burri (2005), Steck (1998, 2008), Berger and Mercolli (2006), Matasci et al. (2011) and

\subsubsection{The Leventina nappe}

The Leventina nappe is formed of a leucocratic, two micas granite gneiss (Casasopra 1939). It occupies the hinge zone of the NW-striking Ticino dome between Claro and RodiFiesso in the Leventina valley. It is separated from the higher Simano nappe by a quartzitic and mylonitic shear zone that passes at Chiggiogna in a zone of Triassic quartzite and dolomite (Fig. 2; Rütti et al. 2005; Berger et al. 2005).

\subsubsection{The Antigorio nappe}

The Antigorio fold nappe in the Antigorio (Toce) and Devero valleys is composed of three granitoid intrusions: (a) the $296 \pm 2 \mathrm{Ma}$ old Antigorio tonalite, (b) the dominant middle to coarse grained $290 \pm 4$ Ma old Antigorio granodiorite and (c) the $289 \pm 4$ Ma old Antigorio granite (Bergomi et al. 2007). The Antigorio granitoids are farther east intrusive in an older polycyclic and migmatitic unpublished documents by Paul Graeter $\left(^{\dagger}\right)$ and Eduard Wenk $\left(^{\dagger}\right)$ (A high-resolution version of this figure appears as Electronic Supplementary Material with the online version of the article and can be found as a fold-out at the back of the printed issue)

basement. The granodiorite is also intrusive in the Paleozoic Baceno schist of the Devero valley and the Verampio window. The Pioda di Crana gneiss is dominated by a strongly foliated middle to fine grained $301 \pm 4$ Ma old granite gneiss (Bergomi et al. 2007). Locally and especially near the contact with the higher Mergoscia zone, polycyclic micaschists and amphibolites are common. The granodioritic and tonalitic Alpigia hornblende-biotite gneiss, here attributed to the Antigorio nappe, exhibits a regular contact with the staurolite-kyanite-garnet-micaschist of the Campo Tencia unit of the Simano nappe (Keller et al. 1980; Steck 1998; Berger et al. 2005). This contact may be tectonic or intrusive.

\subsubsection{The Teggiolo zone}

The Teggiolo zone is the autochthonous sedimentary cover of the Antigorio and Verampio nappes. Its age ranges from Triassic to Eocene and it comprises several sedimentary 


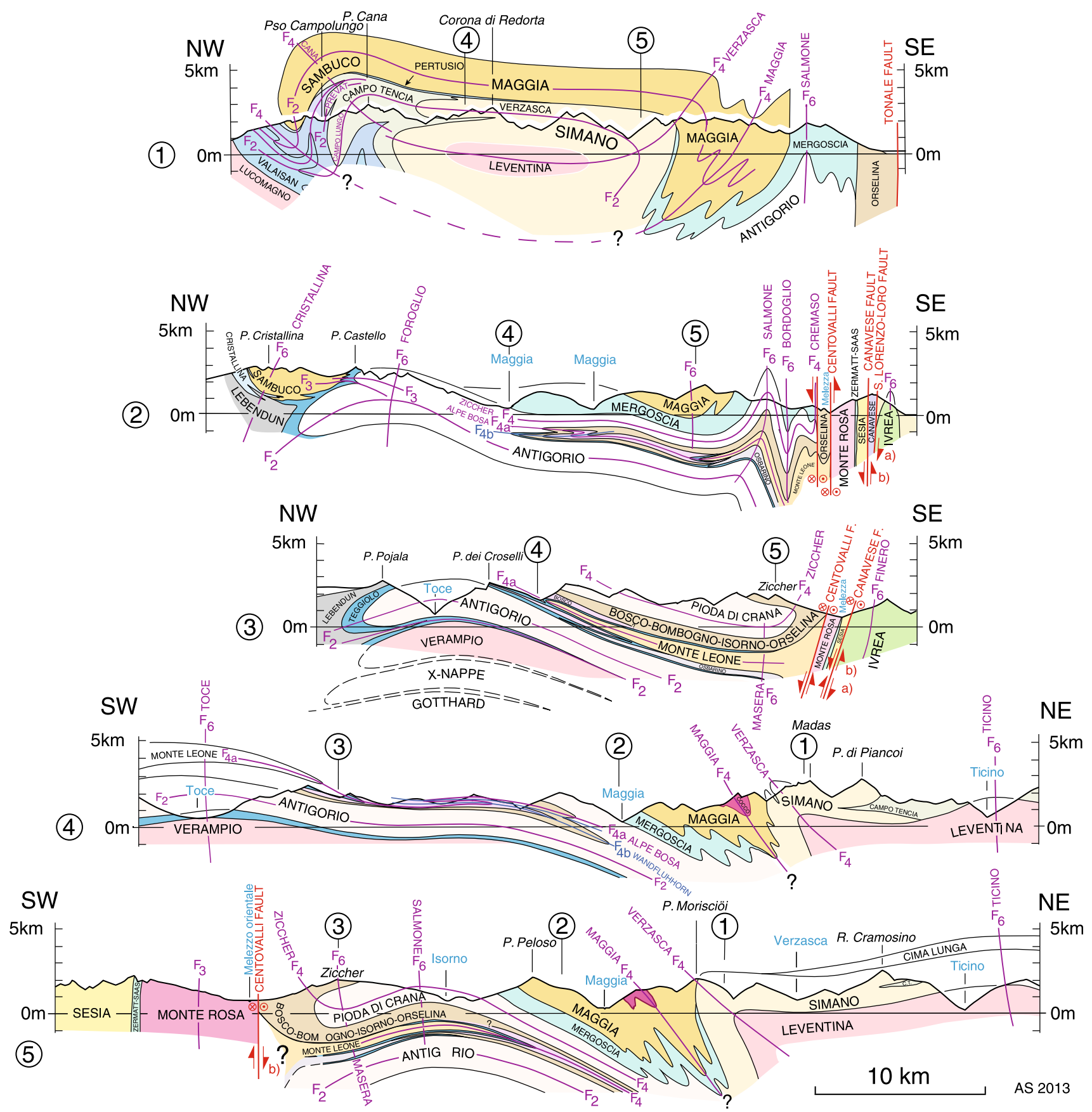

Fig. 3 Structural cross-sections through the Lepontine gneiss dome (for locations, see Fig. 2)

cycles composed of Triassic quartzites, metapelites and dolomites, Jurassic to Lower Cretaceous marbles and Upper Cretaceous to Tertiary flysch and wildflysch, separated by erosive surfaces and large stratigraphic gaps. The main mass of the Teggiolo calc-schists, whose base truncates the Triassic-Jurassic cycles and the Antigorio basement consists of flysch deposits of Late Cretaceous to Eocene age of the North-Penninic (or Valais s.l.) basins. Thus, the Antigorio-Teggiolo domain occupies a palaeogeographic position at the boundary between the Helvetic and Penninic realms (Matasci et al. 2011). A $10 \mathrm{~m}$ thick band of calcite marble exposed along the Sentiero dei Vanisc (VANISC on map Fig. 2) is attributed to the Upper Jurassic of the Teggiolo zone.

\subsubsection{The Simano nappe}

On their tectonic map of the Simano nappe, Keller et al. (1980) distinguished a northern Campo Tencia unit composed of staurolite-kyanite-garnet micaschist and biotite- 
Table 1 List of the Alpine tectonic units from the western and eastern Lepontine area represented from north to south in their respective paleogeographic positions, with the distinction between the polycyclic basement (bold letters), the related postPermian Mesozoic and Cenozoic sedimentary cover (italics) and the ophiolites (bold letters), modified after Geologische and Tektonische Karte der Schweiz 1:500,000 (Spicher 1980; Swiss Geological Survey 2005), Steck et al. (1999, 2001), Berger and Mercolli (2006) and Steck (2008)

Fig. 4 Palaeogeographic map of the Alpine Tethys preceding the Tertiary collision of Europe and Adria (modified after Masson 2002; Bernoulli et al. 2003; Gianreto Manatschal, personal communication; Galster et al. 2012). The regional distribution of the different continental and oceanic units is deduced from the kinematic model of the Central Alps discussed in this paper, with emphases on the European continental margin and the Valais basin. The green star indicates the position of the Sabbione basaltic volcano (Carrupt 2002)

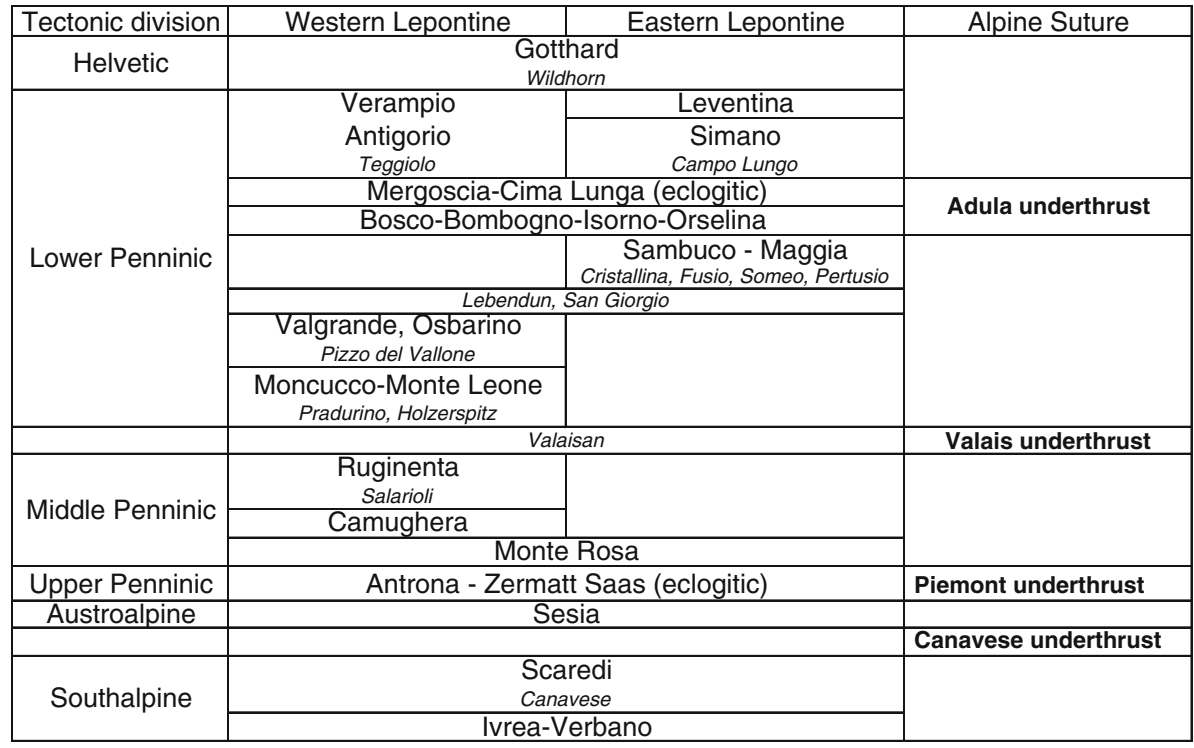

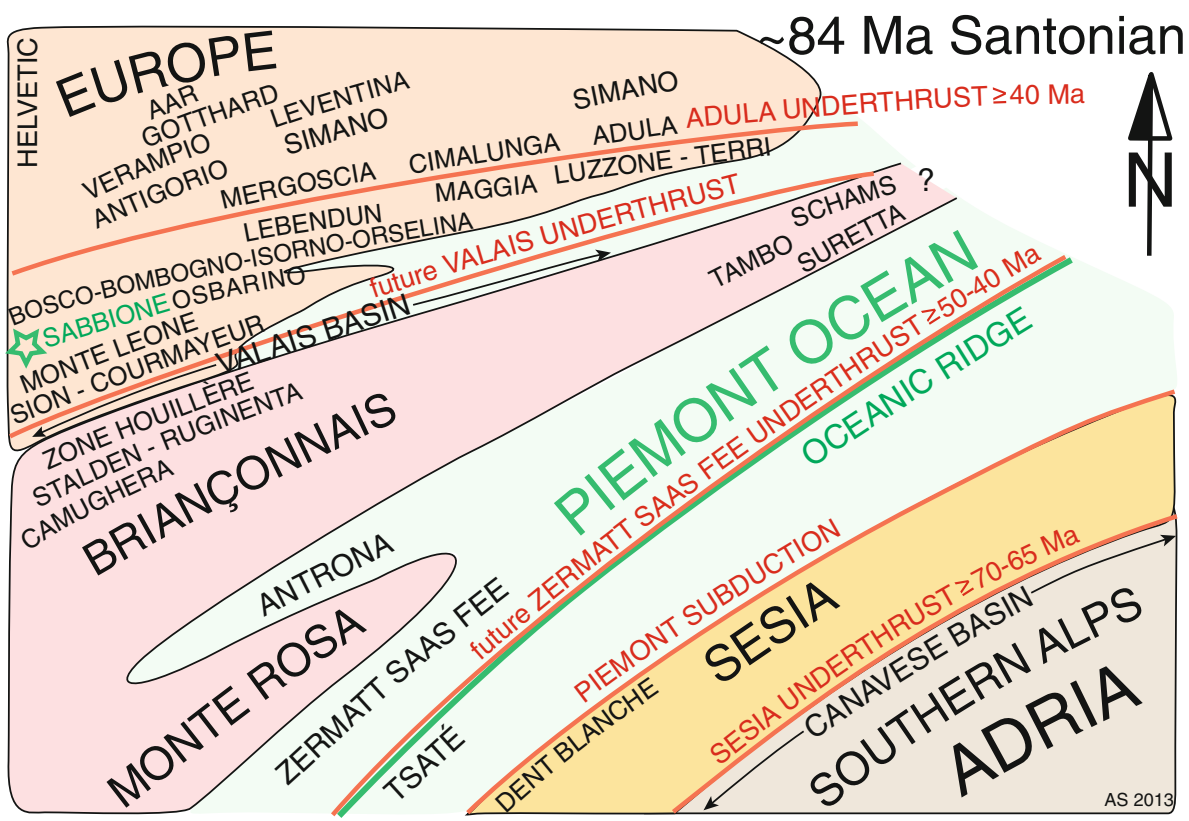

plagioclase paragneiss (meta-graywacke), the latter intruded by the Ganna granite gneiss, from a southern zone, dominated by a granitic two mica augengneiss, the $300 \mathrm{Ma}$ old Verzasca gneiss (Köppel et al. 1981). A discontinuous zone of amphibolites follows the contact of the two units. The contact of the Campo Tencia and Verzasca units resemble a shear zone (Keller 1968).

\subsubsection{The Campolungo zone}

The Campolungo sedimentary cover of the Simano basement is characterised by a $1-10 \mathrm{~m}$ thick basal quartzite (Lower Triassic?), a 30-100 m thick level of white and grey graphitic dolomites (Middle Triassic?) and 8-50 m of cargneule (Upper Triassic?) of a Triassic age overlain by post-Triassic calc-schists. The Triassic quartzite overlies an up to $10 \mathrm{~m}$ thick conglomeratic quartzitic gneiss (locally with carbonate) of uncertain Permian age and a two mica garnet, \pm staurolite and kyanite gneiss or schist of the Campo Tencia basement. The Campolungo zone is folded to the west by the Mogno and to the east by the Alpe Piota syncline (Bianconi 1971; Keller et al. 1980). In our interpretation (Figs. 2, 3), the Campolungo zone does not represent the "Mulde" (syncline) postulated by Hasler (1949) nor the continuous Mogno syncline proposed by Maxelon and Mancktelow (2005, Fig. 16). 


\subsubsection{The (eclogitic) Mergoscia and Cima Lunga units and the (amphibolite facies) Bosco-Bombogno- Isorno-Orselina zone}

The amphibolite facies Bosco-Bombongo-Isorno-Orselina zone replaces the former Bosco-Isorno-Orselina zone, defined by Hunziker (1966), Wieland (1966) and adopted by Steck (2008). The Bosco and Bombogno zones were at first distinguished by Grütter (1929), Hunziker (1966) and Wieland (1966). New fieldwork by Franco Della Torre and Luca Maggini provides a better knowledge and more precise limits of the two units. The Bosco unit is exposed in the Alpe Bosa, Bosco and Wandfluhhorn region and continue as a small layer in the Isorno valley with an uncertain southern continuation, whereas the Bombogno unit has its southern continuation in the Bosco-Bombogno-IsornoOrselina zone. The Bosco unit is composed of micaschist and leucocratic muscovite-biotite-K-feldspar-oligoclase gneiss. The very heterogeneous zone of para- and orthogneisses, amphibolites, meta-gabbros, ultramafites, calcschists and marbles of the Bombogno unit continue to the south into the similar Isorno zone. Wieland (1966) observed the continuity between the Isorno and Orselina zones across the Masera syncline, an observation that has been confirmed by Bigioggero et al. (1981a, b) and Steck (2008). The eclogitic Mergoscia and Cima Lunga units and the amphibolite facies Bosco-Bombogno-Isorno-Orselina zone have a very similar lithology and occur in the same tectonic position on top of the Antigorio and below the Maggia nappes to the east and below the Osbarino unit and the Monte Leone nappe to the west, in the WandfluhhornAlpe Bosa fold structure. The delimitation of the eclogitic Mergoscia unit from the Antigorio nappe is arbitrary and only based on the presence or absence of rare eclogite relicts. The very heterogeneous Mergoscia and BoscoBombogno-Isorno-Orselina units are composed of polycyclic basement rocks, granite gneiss, ophiolites and calcschists, the latter of a probable Mesozoic age. The heterogeneity of these units indicates a strong deformation by folding and boudinage of more competent layers. Only a detailed mapping can show if the term "tectonic mélange" used by Trommsdorff (1990) and Engi et al. (2001a, b) is justified. Berger et al. (2005) attribute these units to a Paleogene tectonic accretion channel. Contrary to them, we distinguish in this zone, (1) the Mergoscia and Cima Lunga units characterised by Paleogene eclogites and their relicts, later overprinted by the Oligocene amphibolite facies regional metamorphism, from (2) the Bosco-BombognoIsorno-Orselina zone of the southern steep belt that was only overprinted by a Oligocene amphibolite facies metamorphism. All these units occur in the same Adula suture zone (cf. Fig. 4; Table 1), where they were underthrust to different depths, metamorphosed and later extruded and accreted. The occurrence of elements of oceanic crust (ultramafites, metagabbros, amphibolites) and calc-schists suggest the existence of a Cretaceous-Paleogene marine basin that was situated between the European Antigorio and Monte Leone nappe domains. The suggested Palaeogene age of the eclogites of the Mergoscia zone is not supported by radiometric data, but it may be similar to the ca. $40 \mathrm{Ma} \mathrm{Sm}-\mathrm{Nd}$ and $\mathrm{Lu}-\mathrm{Hf}$ ages obtained for the Alpe Arami and Cimalunga eclogites situated in a same tectonic position (Becker 1993; Brouwer et al. 2005; Herwartz et al. 2011; cf. Table 1).

\subsubsection{The Maggia nappe}

The Sambuco and Maggia units are represented on the Tectonic map of Switzerland (Fig. 5a; Spicher 1972, 1980; Tektonische Karte der Schweiz, 1:500,000, 2005) and by Grujic and Mancktelow (1996) and Maxelon and Mancktelow (2005) as a unique continuous Maggia nappe. The Campolungo sediments of the Mogno syncline are connected with the Pertusio zone. However, the detailed fieldwork of Keller et al. (1980) and Stefan Kröner (personal communication) has shown that the latter connection does not exist. The staurolite-kyanite-bearing garnet two mica schist of the Simano nappe turn at Fusio as a continuous zone around the Mogno antiformal syncline (Fig. 3 in Steck 1998). The Maggia nappe is exposed in the two Sambuco and Maggia klippes separated by the Antigorio and Simano nappes. The two triple points between the limits of the Sambuco, Antigorio and Simano and the Antigorio, Simano and Maggia units respectively, testify of the overthrust of the older Antigorio and Simano nappes by the younger Maggia nappe (Figs. 2, 5c). Another solution is a connection of the Sambuco and Maggia units through the Alpigia granodiorite and tonalite. The Alpigia granodiorite and tonalite has a very similar magmatic texture with characteristic biotite agregates as the Matorello and Cocco intrusions (Preiswerk in Niggli et al. 1936) and may belong to the Maggia nappe (Fig. 5b). The amphibolite layer that separates the Alpigia pluton from the Sambuco unit is a strange feature in this interpretation. The Maggia nappe is composed of polycyclic basement gneisses intruded by the late Carboniferous $300-304 \pm 8 \mathrm{Ma}$ old Matorello and the $308 \pm 7 \mathrm{Ma}$ old Cocco and Ruscada granites, granodiorites and tonalites (U-Pb zircon ages, Bussien et al. 2011). The lithological similarity of the Cocco and Matorello granodiorites and tonalites led Preiswerk (1921) and Bossard in Niggli et al. (1936) to conclude that the Maggia nappe represents a continuous transverse Maggia structure. Bossard considered it as a transverse root zone between the Simano gneisses in its roof to the east and the Antigorio-Pioda di Crana gneisses below to the west. Bossards idea has been taken over by 


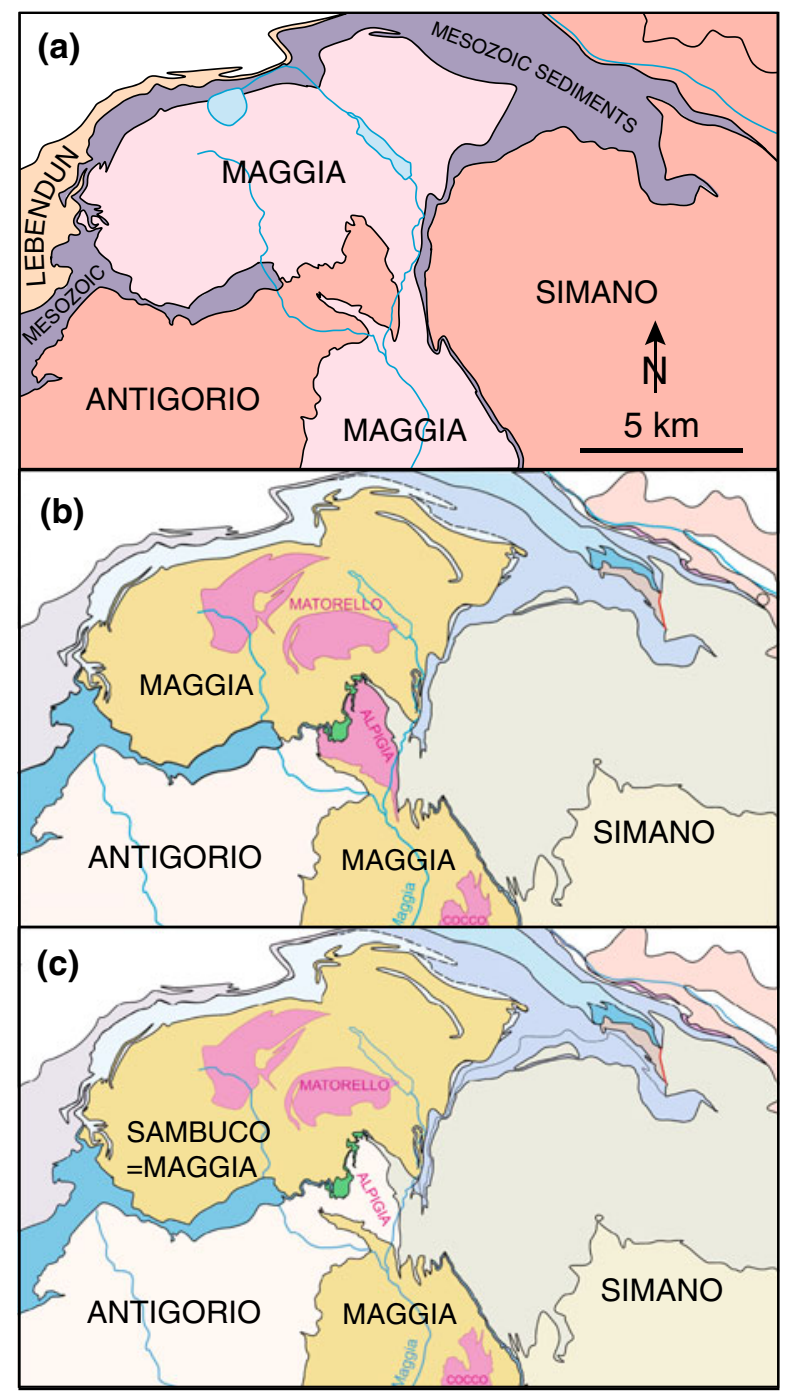

Fig. 5 Three models for the structural relations between the Sambuco, Maggia, Antigorio and Simano units in the region of Peccia and Fusio in the upper Maggia valley. a On the Tektonische Karte der Schweiz (2005), the Sambuco and Maggia units are connected by a strip of gneisses and the Campolungo Mesozoic sediments continue in the zone of Pertusio. This model is contrary to Keller et al. (1980) and new fieldwork. b In this model it is suggested that the Alpigia granodiorite and tonalite forms an integral part of the Maggia nappe. The Alpigia granodiorite and tonalite are similar to the Matorello and Cocco intrusions (Grütter and Preiswerk in Niggli et al. 1936). The textures of this granitoids are characterized by biotite aggregates also typical for the Matorello and Cocco intrusions. c On the model proposed in this paper (Fig. 2) the Maggia and Sambuco units represent two klippes of a single Magga nappe. The two triple points between the Antigorio, Sambuco and Simano units to the north and between the Antigorio, Maggia and Simano units to the south may be explained by a younger overthrust of the Maggia-Sambuco son the older Antigorio and Simano nappes. In any case, the Antigorio basement with its Helvetic Mesozoic cover sequence (Teggiolo zone) and the Simano basement with its Penninic Mesozoic sediments (Campolungo zone) are different and the structural relations of the Antigorio and Simano nappes are in all three models open to question. Model $\mathbf{c}$ is our preferred interpretation of the Alpine structures of the Peccia and Fusio region, but model $\mathbf{b}$ is also possible and cannot be excluded
Simpson (1982), Grujic and Mancktelow (1996) and Maxelon and Mancktelow (2005). In this paper, the view of Keller et al. (1980) according to the geological map Campo Tencia is adopted, which considers the Sambuco and Maggia units representing two synformal klippes that are separated in the region of Fusio by the Antigorio-Alpigia gneisses and the staurolite-kyanite-garnet micaschist of the Campo Tencia sub-unit (Fig. 2). Geopetal upside down magmatic structures in the Matorello region were overturned during a younger phase of folding (Bussien et al. 2011). This observation is compatible with the interpretation of the Tertiary F2 fold nappe geometry of the Maggia nappe. The contacts of the Sambuco unit with the Mesozoic calc-schist of the Campolungo cover of the Campo Tencia unit of the Simano nappe and the Mesozoic Teggiolo cover of the Antigorio basement are tectonic. The lower contact of the Maggia nappe with the neighbouring units is complex and also tectonic.

\subsubsection{The Cristallina zone}

The Cristallina zone represents the autochthonous Mesozoic sedimentary cover, well developed on the northern border of the Sambuco basement. This zone has been studied by Jean-Yves Délèzes and Florence Lodetti for their MSc theses at Lausanne University in the Cristallina and Lago di Narèt regions. This sedimentary cover is affected to the north of the Pizzo Cristallina, together with the higher Lebendun sediments by three phases of isoclinal folding F1-F3 and resembles the autochthonous sedimentary cover of the Helvetic Gotthard and Mont Blanc massifs (personal communications). The sequence starts with about $1 \mathrm{~m}$ of Triassic meta-arkose, quartzite and greenish micaschist and over $5 \mathrm{~m}$ of dolomitic marble with $20-30 \%$ of calcite and ends with up to $10 \mathrm{~m}$ of an alternation of sandstone, micaschist and calc-schist with detrital dolomite attributed to the Rhaetian. The passage to the next over $15 \mathrm{~m}$ thick sequence, an alternation of micaschist, calc-schist and marbles is gradual and ends with quartzites with mica, garnet, staurolite and kyanite. These sediments are attributed to the Early Jurassic. They are followed by over $25 \mathrm{~m}$ thick dark graphitic micaschist with garnet, staurolite and kyanite attributed to the Aalenian. A $350 \mathrm{~m}$ long slice of the Cristallina zone is exposed at the Cimetta Briolent (point $2,172 \mathrm{~m}$ and Swissmap coordinates $695.025 \mathrm{~km} / 146.250 \mathrm{~km})$ on the contact between the Sambuco unit and the Campolungo zone. The Sambuco basement to the west is overlain by $70 \mathrm{~m}$ of arkosic conglomerate of probably Permo-Carboniferous age, followed by the Triassic composed of about $1 \mathrm{~m}$ of quartzite rich in white mica, $6 \mathrm{~m}$ of dolomite marble, $1 \mathrm{~m}$ of micaceous quartzite, $4 \mathrm{~m}$ of dolomite marble, followed by a $1-2 \mathrm{~m}$ thick layer of a ochre collared banded sandy calcite marble 
attributed to the Lower Jurassic, the latter in tectonic contact with the quartz-rich calc-schist of the Campolungo zone to the east (Bianconi 1971).

\subsubsection{The Fusio zone}

White calcite marble occur at the village of Fusio in decametre thick bands inside of the Sambuco basement near the tectonic contact with the calc-schist of the Campolungo cover of the Simano nappe. The calcite marble outcrop in the village of Fusio contains some quartz and mica to the west and passes to a pure white (brownyellow weathering) calcite marble to the east. The sequence may be interpreted as a slice of middle to upper Jurassic marble. No similar sediments exist in the nearby Cristallina and Campolungo zones.

\subsubsection{The Pertusio zone}

The Pertusio zone is a strongly deformed zone, mainly composed of some metres thick horizon of white quartzite of uncertain probably Triassic age with numerous up to some centimetres thick bands of calcite marble of a possible Upper Jurassic age that marks the limit between the Maggia and Simano nappes between Monte Zucchero to the south and Peccia to the north (Fig. 2; Keller et al. 1980).

\subsubsection{The Someo zone}

The term Someo zone is defined and restricted in this paper in accordance with Preiswerk et al. (1934) to a decimetre to some metres thick band of white calcite marble and associated quartzite, micaschist and amphibolite that marks the limit between the Mergoscia and Maggia units. It is not possible to attribute this zone to one of the two adjacent units. The Someo zone is composed north of Someo of an up to $4 \mathrm{~m}$ thick band of white calcite marble. At its border it is associated with centimetre to decimetre thick bands of quartzite, amphibolite and some garnet micaschist. Two bands of up to $60 \mathrm{~cm}$ thick white calcite marble are associated with garnet micaschist and decametric bands of amphibolite in the Maggia riverbed southeast of Brontallo (Fig. 2; Keller et al. 1980). Eclogite relicts are missing in the amphibolite layers of Someo and Brontallo. The new definition of the Someo unit by Berger et al. (2005), who associate in the Someo unit the marbles of Preiswerk's Someo zone with the gneiss, schists, eclogitic amphibolites, ultramafites and marbles of our herein defined Mergoscia unit, is for this reason rejected and replaced by the original definition of Preiswerk et al. (1934). It is speculated that the white marble of the otherwise very different Fusio, Pertusio and Someo sedimentary sequences may belong to a same possibly Upper Jurassic marble horizon of the Sambuco-Maggia nappe.

\subsubsection{The Lebendun nappe}

The Lebendun nappe is composed of a polymictic conglomerate and a micaschist ("schisti bruni", Burckhardt 1942; Burckhardt and Günthert 1957; Joos 1969). Pebbles of Triassic dolomite testify the post-Triassic, possibly Cretaceous age of these sediments (Rodgers and Bearth 1960; Spring et al. 1992). It occupies a large zone to the north of the Antigorio nappe and Sambuco unit. Another up to $50 \mathrm{~m}$ thick band of Lebendun conglomerate is exposed on the mountain ridge to the north of the Pizzo di Bronzo in the upper Valle dell'Isorno, between the Bosco zone on top and the Antigorio gneiss at the base. The tectonic position of the Lebendun conglomerates suggests that they have been thrust from the south of the Maggia and the north of the Monte Leone nappes (Fig. 4). The San Giorgio unit occurs in a similar tectonic position in front of the Simano nappe. It is composed of metapsammite and metapsephite gneisses and Triassic phlogopite dolomite and cellular dolomite and represents after Burckhardt (1942) an eastern equivalent of the Lebendun nappe. Bianconi (1971), Berger and Mercolli (2006) and Galster et al. (2010, 2012) propose the San Giorgio unit as an equivalent of the Soja unit that has nothing to do with the Lebendun unit.

\subsubsection{Osbarino and Valgrande units}

The Osbarino unit (named herein after the Pizzo Osbarino, located between the Toce and Isorno valleys, Fig. 2) is dominated by well foliated, leucocratic muscovite-biotitegranite gneiss. It may correspond to a southwestern continuation of the Bosco unit and continue farther west in the Valgrande gneiss. Schmidt and Preiswerk (1905) and Wieland (1966) distinguish this gneiss as the "Lebendun"Zug and consider it with the Valgrande gneiss as the basement of the Lebendun conglomerates. We propose that the Valgrande gneiss represents the basement of the newly defined Pizzo del Vallone nappe of Mesozoic sediments (Carrupt 2002), whereas the Mesozoic Lebendun conglomerate and "schisti bruni" are considered as a rootless thrust sheet.

\subsubsection{The Monte Leone nappe}

The Monte Leone gneiss occupies the central part of the Alpe Bosa fold, situated between the Toce, Isorno and Bosco valleys and is separated from the Osbarino and Bosco-Bombogno-Isorno-Orselina units by a sheet of Mesozoic calc-schist, garnet mica schist and marble (Figs. 2, 3). The calc-schist forms only a discontinuous 
horizon of lenses on the contact with the similar Osbarino gneiss between Monte Crestese and Alpe Agarino (to the west of the Toce valley). The Monte Leone unit in the Isorno valley is composed of a tabular, fine to middle grained biotite-K-feldspar-oligoclase gneiss (Wieland 1966). The Moncucco unit is attributed in accordance with Milnes in Steck et al. (1979) (Milnes and Müller in Trümpy $1980)$ to the Monte Leone nappe. The $271 \pm 4.8 \mathrm{Ma}(\mathrm{Rb}-$ Sr age, Bigioggero et al. 1981a, b) old Moncucco biotitemuscovite-K-feldspar-oligoclase-gneiss is exposed in two quarries on the eastern (left) wall of the Valle d'Ossola, in a symmetric position to the axial trace and a paragneiss in the centre of the Vanzone anticline situated behind the Trattoria Isola on the Masera-Beura road (Fig. 2; Steck 2008). The Holzerpitz Mesozoic sedimentary cover of the Monte Leone nappe was studied by Carrupt (2002) is not exposed in the studied area (Fig. 2).

\subsubsection{The Valais units}

A large mass of calc-schists is exposed to the north of the Monte Leone and Lebendun nappes, representing the sediments of the Valais basin, of mainly Cretaceous and Palaeogene age. 40-35 Ma is given by Paleocene-Eocene Radiolarian in Sion-Courmayeur zone near Sion (Bagnoud et al. 1998). Berger and Mercolli (2006) attributed them to the Grava nappe and another part to the San Giacomo unit. The latter are related to the Sion-Coumayeur zone farther west.

\section{Tectonic units surrounding the Lepontine dome (Middle-Upper Penninic, Austroalpine, South Alpine)}

This third chapter gives a brief description of the higher tectonic units of the Middle-Upper Penninic, Austroalpine and South Alpine domains that are involved in the structural evolution of the Lepontine gneiss dome. The complete analysis of the structural evolution of these internal Alpine tectonic units lies outside this study.

\subsection{The Ruginenta and Camughera units}

The Ruginenta and Camughera units (Steck 2008) are in accordance with Milnes in Steck et al. (1979) (Milnes and Müller in Trümpy 1980) correlated respectively with the Berisal-Upper Stalden and Siviez-Mischabel nappes (Escher et al. 1997; Steck et al. 2001; Steck 2008). Both units are composed of strongly foliated coarse-grained, biotite augengneiss and polycyclic basement gneiss. The Carboniferous and Triassic Salarioli sedimentary cover of the Ruginenta basement (Steck 2008) is not exposed in the herein studied area. Sartori et al. (2006) and Genier et al. (2008) suggest that the Upper Stalden and Berisal gneiss represent the basement of the Zone Houillère.

\subsection{The Monte Rosa nappe}

The Monte Rosa nappe, exposed to the west of the area described in this paper, was studied in detail by Bearth (1952) and between the Ossola valley and the Loana valley by Reinhardt (1966). The Monte Rosa nappe is composed in the southern steep belt of a coarse-grained biotite-Kfeldspar-oligoclase augengneiss. It is dated by Pawlig and Baumgartner (2001) (U-Pb zircon age) at $302 \pm 6 \mathrm{Ma}$. On the left side of the Valle d'Ossola, in the Rio di Menta valley, it contains a band of staurolite-kyanite-garnetmuscovite-biotite schist that reveals the F3 anticlinal fold structure in the root of the Monte Rosa nappe (dashed lines

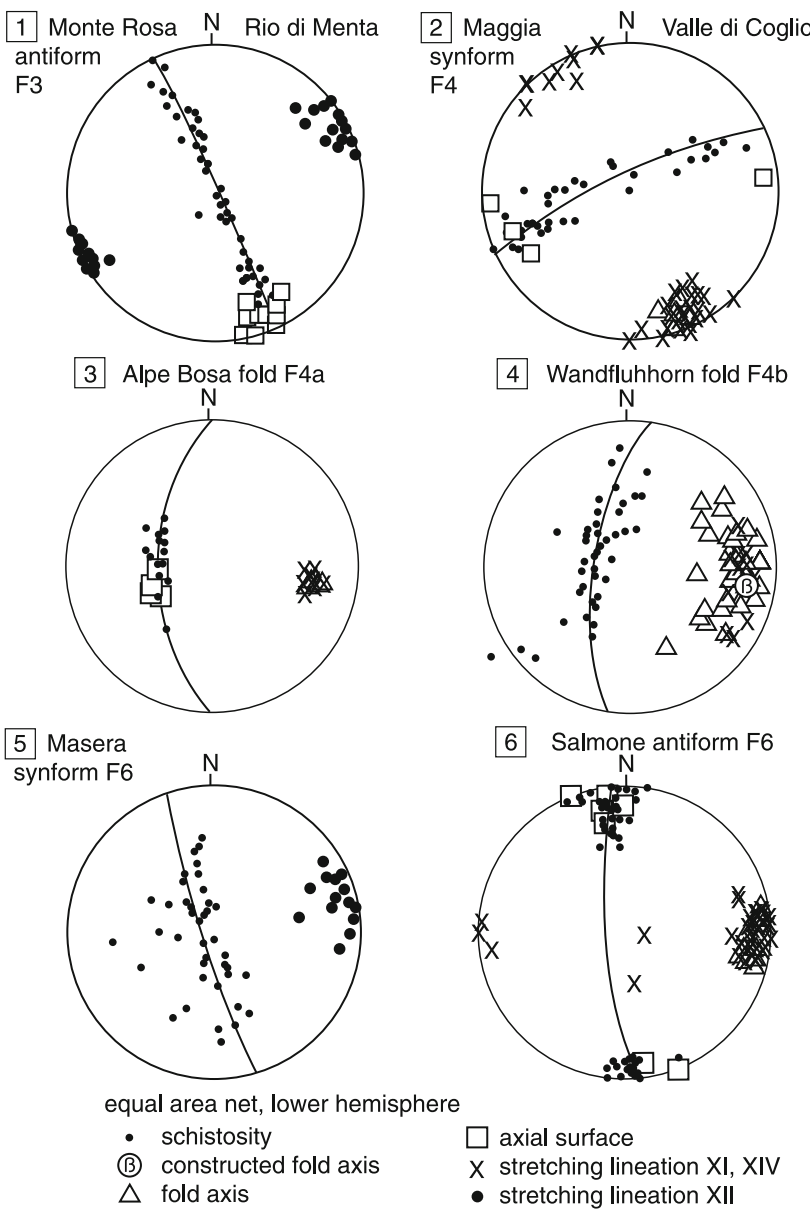

Fig. 6 Steregrams of selected Alpine fold structures in the Lepontine gneiss dome (equal area projection, lower hemisphere): 1 the Monte Rosa F3 anticline, 2 the Maggia F4 syncline, 3 the Alpe Bosa fold F4a, 4 the Wandfluhhorn fold F4b, 5 the Masera syncline F6 and 6 the Salmone anticline F6 (see localities $1-6$ on Figs. 2 and 7). Symbols for schistosity and axial surface represent the poles to these planar structures 
on Fig. 2, stereogram 1 on Fig. 6; see Reinhardt 1966; Steck 1984). No relicts of the Eocene high-pressure metamorphism have been found in the root zone of the Monte Rosa nappe between the Toce River and Locarno.

\subsection{The Antrona and Zermatt-Saas Fee zones}

These two units are composed of Alpine ophiolites with eclogite relicts (Colombi 1989; Pfeifer et al. 1991). The $163.1 \pm 2.4$ and $158 \pm 17 \mathrm{Ma}$ old Antrona ophiolite (SHRIMP U-Pb zircon ages, Liati et al. 2005) is cut by the Centovalli fault to the south of Druogno in the Valle Vigezzo. In contrast, the $164 \pm 2.7$ and $163.5 \pm 1.8 \mathrm{Ma}$ (SHRIMP U-Pb zircon ages, Rubatto et al. 1998) old, Early-Late Jurassic, Zermatt-Saas Fee ophiolites continue farther east on the southern border of the Monte Rosa gneiss, up to the Maggia alluvial delta, and ends there, together with the Monte Rosa nappe, and the Sesia and Canavese zones being cut by dextral faults ("Riedel faults") of the Centovalli and Tonale fault system (Pfeifer et al. 1991). Gebauer (1999) and Amato et al. (1999) dated the Middle Eocene high-pressure metamorphism of the Zermatt-Saas Fee zone to be around 50-40 Ma. The structure and stratigraphy of the Zermatt-Saas Fee and Antrona ophiolitic nappes exposed to the west of the Lepontine gneiss dome was described by Bearth (1967, 1973), Dal Piaz (1965), Sartori (1987). The metamorphic petrology and geochemistry of the mafic rocks of the Antrona and Zermatt-Saas Fee units, exposed in the root zone between Antronapiana to the west and Locarno, was studied by Colombi (1989).

\subsection{The Sesia zone}

The Sesia zone is composed of polycyclic basement gneisses and intruded by late Carboniferous to Early Permian granites and gabbros (Reinhardt 1966; gabbro d'Anzasca, $288+2 /-4 \mathrm{Ma}$, U-Pb zircon age, Bussy et al. 1998). The gabbro and granite gneisses of the "Maia-Zug" were mapped and described for the first time by Walther (1950) in the area of Arcegno-Losone and according to the mapping by Hans-Rudolf Pfeifer are frequently found on the south side of the Vigezzo valley and Centovalli. These rocks of the "Maia-Zug" seem to correspond to the same zone. Black and white marbles are exposed in the upper Valle di Remo to the south of the Centovalli and near Bedruscio to the west of Arcegno. They represent the probably Mesozoic cover of the Sesia basement zone.

\subsection{The Southern Alps}

The Southern Alps form the northwestern border of the Adriatic plate, limited to the northwest from the Sesia zone by the alpine Canavese fault. The Southern Alps are composed of the Canavese zone, the Ivrea-Verbano zone and the Strona-Ceneri zone, delimited by the alpine S. Lorenzo-Loro fault, named herein after the localities S. Lorenzo to the north of Ascona and to the west of the Maggia river and the chapel of Loro in the Valle d'Ossola (Fig. 2; Zingg et al. 1990).

\subsubsection{The Canavese zone}

The rocks of the Canavese zone are together with the southern part of the Sesia zone and the northern border of the Ivrea zone in the neighbourhood of the alpine Canavese and S. Lorenzo-Loro faults strongly deformed into mylonites (Schmid et al. 1989; Zingg et al. 1990). A stratigraphic section through the Paleozoic basement and its sedimentary cover was identified in the Valle Loana. The Canavese zone is composed from south to the north of an amphibolite facies basement gneiss (named Scaredi formation in the Loana Valley) and its autochthonous sedimentary cover, composed of a some decametres thick basal level of probably Permian conglomerate and microconglomerate, decimetre to metre thick Triassic white calcite and dolomite marbles, intruded by basaltic dikes and some decametres of a Liassic black sandy marble (Steck et al. 2001). The Canavese zone is attributed according to Ferrando et al. (2004) to the Southern Alps.

\subsubsection{The Ivrea-Verbano zone}

The mafic main body ("basischer Hauptzug", e.g. Zingg et al. 1990) of the Ivrea zone is composed of bronzitediopside-hornblende ( \pm garnet)-anorthite-amphibolites and phlogopite and hornblende lherzolites associated with stronalites (granulite facies quartz-sillimanite-garnet-anorthoclase rocks). Rare marbles are distinguished by the occurrence of diopside and olivine from the greenschist to lower amphibolite facies Triassic marbles of the Canavese zone. The Ivrea-Verbano zone represents a polycyclic lower crust basement, overprinted by a Permian granulite facies high temperature and low-pressure regional metamorphism, dated of $290 \mathrm{Ma}$ by Henk et al. (1997) (U-Pb monazite age). The high temperature Permian crystallisation and chemical homogenisation excludes the radiometric dating of older metamorphic phases. A Tertiary greenschist facies overprint associated to shear zones and folds is observed over $1 \mathrm{~km}$ inside of the northern part of the Ivrea-Verbano zone. The Variscan higher amphibolite facies Finero antiform was during the Tertiary alpine compression, together with the S. Lorenzo-Loro and Canavese faults, deformed by an alpine F6 greenschist facies fold (Fig. 2; Steck and Tièche 1976). Wolff et al. (2012) discuss the cooling and exhumation history of the Ivrea-Verbano 
Zone using K/Ar dating of mica and illite-rich fault gouges as well as zircon fission track and (U-Th)/He thermochronology, including the adjacent Sesia-Lanzo Zone and Penninic nappes. The exhumation of the Ivrea Zone took place in three steps. (A) During the Middle Jurassic time the Ivrea zone was exhumed to shallow crustal position by crustal extension. (B) A minor cooling event of the Late Eocene is dated by $\sim 38 \mathrm{Ma}$ zircon fission track ages. (C) The final exhumation is documented by ca. $14 \mathrm{Ma}$ zircon (U-Th)/He ages and a $12.8 \mathrm{Ma} \mathrm{K} / \mathrm{Ar}$ fault gouge age. The latter fault gouge age is in accordance of the 14-4 Ma age of fault gouges of the Centovalli Line obtained by Surace et al. (2011). The tectonics of the Ivrea zone was discussed by Zingg et al. (1990), Handy and Zingg (1991), Henk et al. (1997) and Handy et al. (1999). A further discussion of the tectonics of the Southern Alps lies outside of this study.

\section{Alpine structures and metamorphism}

\subsection{The NW-verging Alpine nappe stack and F1-F3 folds}

The NW-verging stack of Alpine nappes is best exposed in the classic Simplon transect to the west of the Toce dome and in the Simplon railway tunnel (Schardt 1903; Schmidt and Preiswerk 1905; Argand 1911; Milnes 1973; Steck et al. 1979, 1997; Steck 1984, 1990, 2008, Fig. 5; Escher et al. 1993; Genier et al. 2008; cross-section 3 on Fig. 3). Units such as the NW-directed Aar and Gotthard folds, the $\mathrm{X}$-nappe, the Verampio, Antigorio, Monte Leone nappes have been formed by ductile detachment of the upper European crust during its underthrust to the SE below the upper Penninic and Austroalpine thrust sheets and the Adriatic plate (Steck 1984, 2008; Escher et al. 1993; Epard and Escher 1996; Escher and Beaumont 1997). The ductile deformation occurred at temperatures of $300{ }^{\circ} \mathrm{C}$ in the Lötschen valley, the northern border of the Aar massif fold and over $650{ }^{\circ} \mathrm{C}$ in the Verampio window and the southern steep belt (Fig. 1; Frank 1983; Engi et al. 1995, 2001; Burri et al. 2005; Herwegh and Pfiffner 2005). Up to three schistosities (S1-S3) were developed during a progressive rotational deformation as axial surface schistosities $\mathrm{S} 1$ and S2 and as younger steeper SE-dipping schistosity S3 of the fold nappes and thrusts (Figs. 2, 3, 6, 7, 8; Steck 1984; Matasci et al. 2011). Matasci et al. (2011) described in the Pizzo Castello section the F3 folds with their axial surface that crosses as a discordant structure the Antigorio gneiss, its autochthonous Mesozoic Teggiolo sedimentary cover and the higher Sambuco (Maggia) basement gneiss (crosssection 2 on Fig. 3). A SE-plunging stretching lineation named XI (Steck 1980, 1984, 1990), with top-to-NW shear
Fig. 7 Overview of the axial traces of Alpine fold structures in the Lepontine gneiss dome (extracted from Fig. 2). Note that only a selection of axial traces of the F2-F3 recumbent folds are represented on this figure. The cross-sections on Fig. 3 give more complete information on these phases of folding. Anticline is named on Figs. 2 and 7 an upward closing fold and syncline is named a downward closing fold at the moment of their formation. A synformal anticline is an over turned anticline and an antiformal syncline an over turned syncline. The stratigraphic age relationships can only be used for the definition of anticlines and synclines in the case of F1-F3 folds that deform the Paleozoic basement-Mesozoic sedimentary cover contacts

indicators parallel to a dominant direction of simple shear, was developed on the XY schistosity planes S1-S3. The autochthonous Mesozoic sedimentary cover sequences, the Teggiolo sediments of the Verampio and Antigorio nappes, the Campolungo sediments of the Simano nappe and the Cristallina sediments of the Maggia nappe were accumulated in the frontal NW-verging F2 fold hinges by the simple shear dominated thrusting (Figs. 2, 3). The synmetamorphic middle Penninic Siviez Mischabel nappe emplacement has been dated to $40-35 \mathrm{Ma}\left({ }^{40} \mathrm{Ar} /{ }^{39} \mathrm{Ar}\right.$ white mica in Triassic quartzites, Markley et al. 1998). The Lower Penninic nappes and the Aar and Gotthard basement folds are younger, also younger than the Cimalunga and Adula high-pressure metamorphism, dated by Becker (1993) (Sm-Nd mineral ages) and Herwartz et al. (2011) (Lu-Hf mineral ages) at about 42-37 Ma. This lower Pennine nappe emplacement must also be older than the $32 \mathrm{Ma}$ zircon ages in the Adula nappe (Liati et al. 2009) and the 33-29 Ma porphyritic, 29-25 Ma aplitic and pegmatitic dikes and 32-22 Ma migmatites of the southern steep belt (Romer et al. 1996; Schärer et al. 1996; Rubatto et al. 2009; see Table 2). More complex are the structures and evolution of the higher and older Monte Rosa, Zermatt-Saas Fee, Antrona and Sesia thrust sheets, not treated in this study.

Four deep zones of underthrust, extrusion and accretion were developed from the south to the north in the Alpine orogeny (Fig. 4; Table 1).

1. 1. Alpine subduction started in the Western Alps with the underthrust of the Sesia zone below the Canavese zone of the Southern Alps (Dal Piaz et al. 2001; Babist et al. 2007; Handy et al. 2010). It is dated by its Late Cretaceous 75-65 Ma high-pressure metamorphism (Duchêne et al. 1997; Ruffet et al. 1997; Rubatto et al. 1998; Konrad-Schmolke et al. 2006). The extrusion by $63 \mathrm{Ma}$ and accretion of the Sesia zone on the Canavese zone and Southern Alps was followed by

2. The underthrust of the Piemont oceanic crust starts with the underthrust, extrusion and accretion of the southern Tsaté unit followed by the up to $100 \mathrm{~km}$ deep underthrust of the Zermatt Saas Fee and Antrona ophiolites with their Eocene 50-40 Ma eclogitic 


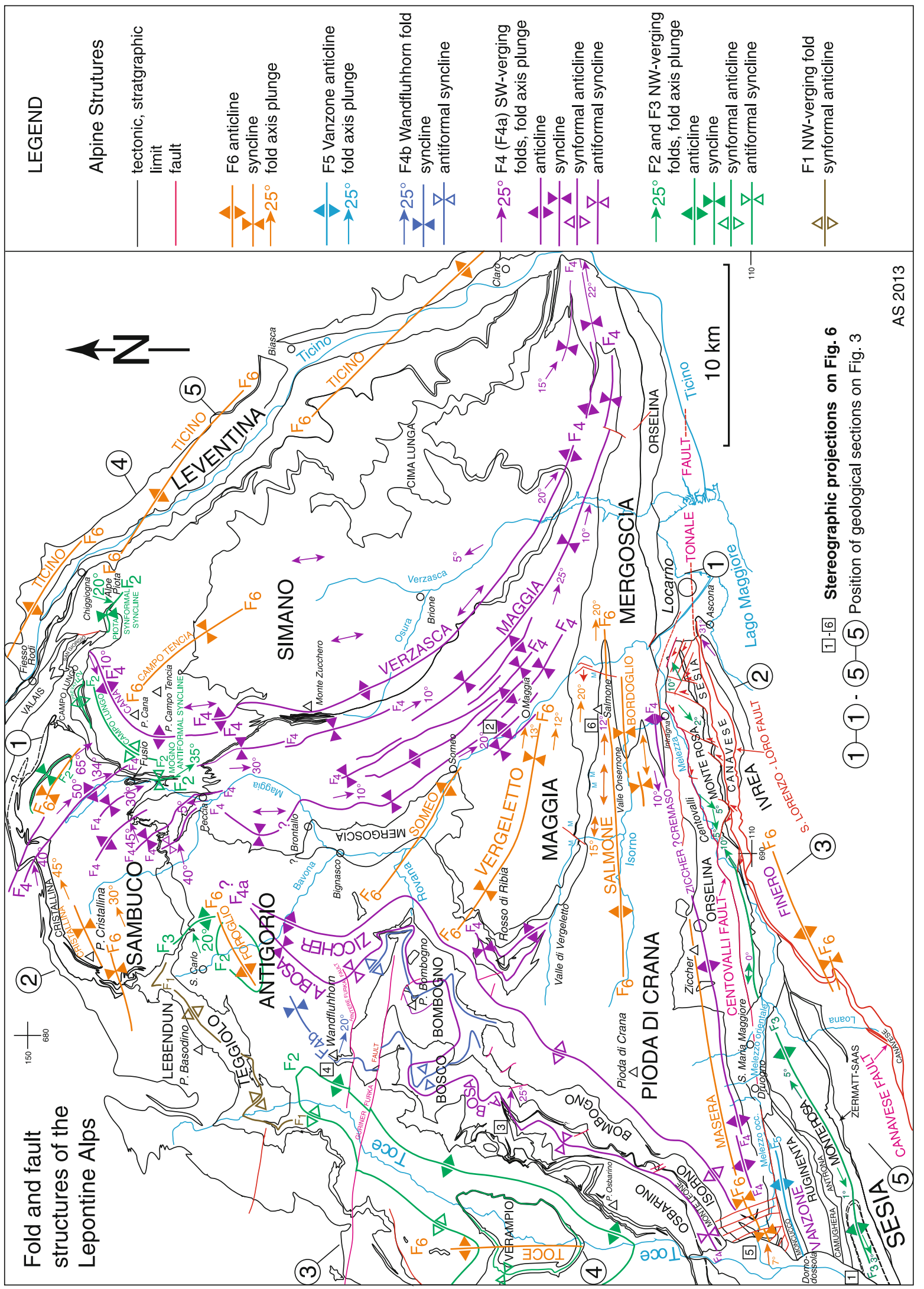




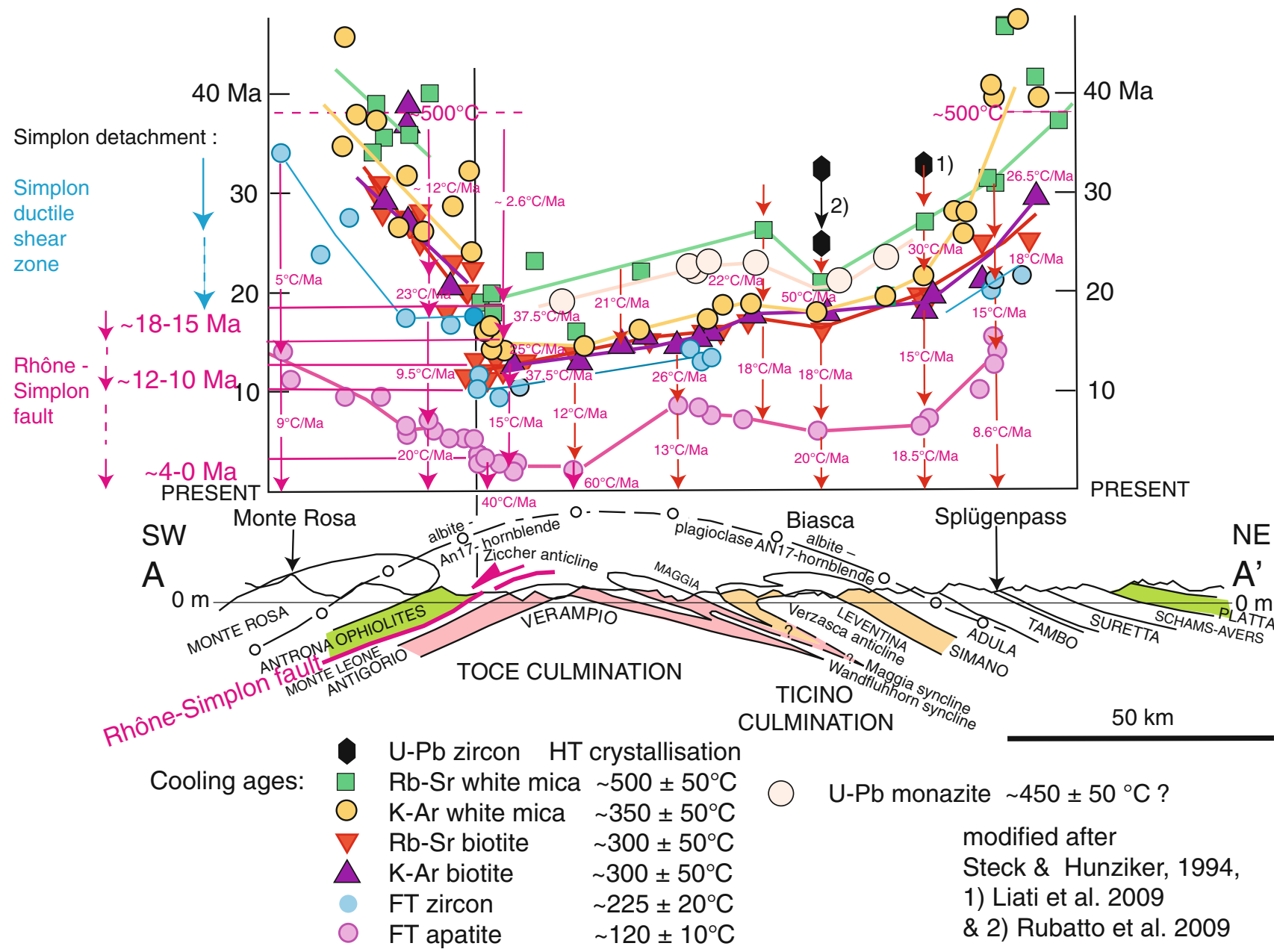

Fig. 8 Cooling ages and rates of the Lepontine gneiss dome (A-A' on Fig. 1) modified after Fig. 12 in Steck and Hunziker (1994; Campani 2011), completed by U-Pb zircon dating of Liati et al. (2009) and Rubatto et al. (2009). (1) High temperature crystallisation (resetting) of zircon in the Adula nappe (Liati et al. 2009). (2) Crystallisation of zircon in Tertiary migmatite leucosome from Bellizona (20 km to the south of profile A-A'; Rubatto et al. 2009). Note that the progressive cooling below $500{ }^{\circ} \mathrm{C}$ started during and after Lower Penninic nappe emplacement some $38 \mathrm{Ma}$ ago at the western and eastern border of the Lepontine dome and was followed by the rapid cooling some $26 \mathrm{Ma}$ ago of the Verzasca F4 anticline (Hurford 1986). 32 Ma zircon U-Pb resetting in the Adula nappe and 32-22 Ma zircon crystallisation in the southern steep belt testify of temperatures of over $650{ }^{\circ} \mathrm{C}$ until $22 \mathrm{Ma}$ (Rubatto et al. 2009). Accelerated cooling continued by uplift and erosion of $50{ }^{\circ} \mathrm{C} / \mathrm{Ma}$ between 23 and $18 \mathrm{Ma}$ of the Ticino dome to the $\mathrm{E}$ and followed by the rapid cooling of the Toce dome to the $\mathrm{W}$, with phases of accelerated cooling by detachment on the Rhone-Simplon low angle normal fault of $37.5^{\circ} \mathrm{C} / \mathrm{Ma}$ between $18-15$ and $12-10 \mathrm{Ma}$ and $40{ }^{\circ} \mathrm{C} /$ Ma since $4 \mathrm{Ma}$. The U-Pb monazite ages obtained by Köppel et al. (1981) suggest a cooling (resetting?) temperature of $\sim 450 \pm 50{ }^{\circ} \mathrm{C}$ (Steck and Hunziker 1994). The Antigorio and Simano nappes are distinguished in red and orange-yellow colour on the cross-section A-A'. They occur in the same tectonic position in the Alpine nappe stack, but the structural relation of the two units is still problematic

40-35 Ma, younger than the Palaeocene-Eocene Radiolarians in carpholite-chloritoid-bearing Valais metasediments of the Central Alps (Bagnoud et al. 1998; Bousquet et al. 2002), situated between the European Monte Leone nappe and the Briançonnais Zone Houillère, Berisal and Siviez Mischabel nappes. Hammerschmidt and Frank (1991) determined 3T-polytype phengite relicts of a high-pressure metamorphism overprinted by a regional amphibolite facies metamorphism, with 2 M-polytype muscovite in the Monte Leone nappe, supporting a deep underthrust of this unit. 
Table 2 Chronology of the Alpine folding phases compared with the Tertiary sedimentation, structural, magmatic and metamorphic events of the Central Alps, modified after Steck et al. (2001) and Steck
(2008), with data from Becker (1993), Brouwer et al. (2005), Herwartz et al. (2011) and Rubatto et al. (2009)

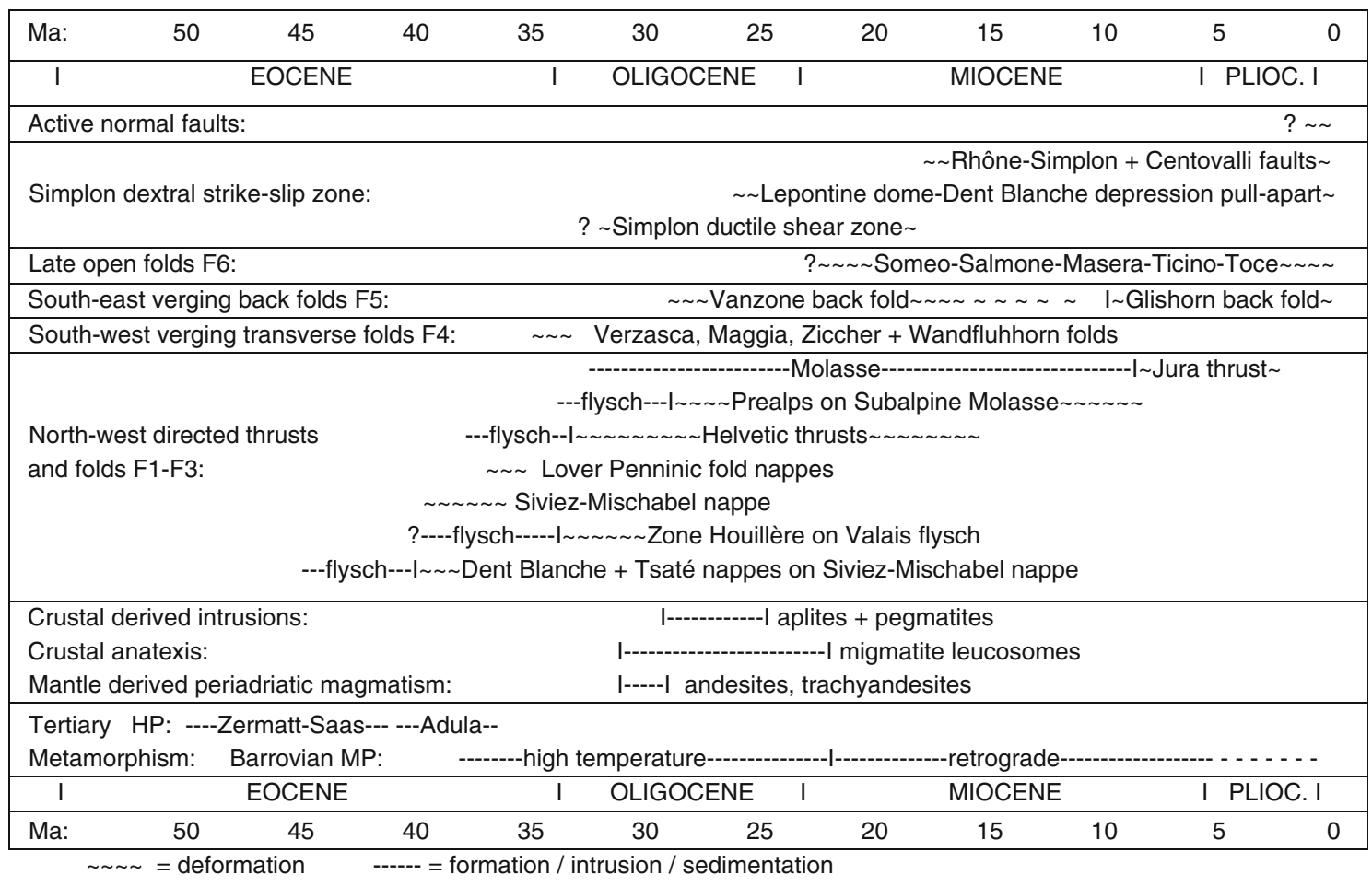

The age data are discussed in the text

4. The deep Adula, Cimalunga and Mergoscia underthrust occurred inside the European crust between the Antigorio and Simano unites, to the north, and the Bosco-Bombogno-Isorno-Orselina, Osbarino, Monte Leone and Maggia units, to the south. $\sim 40 \mathrm{Ma} \mathrm{Sm-}$ $\mathrm{Nd}$ and Lu-Hf ages were obtained for the Alpe Arami and Cimalunga eclogites (Becker 1993; Brouwer et al. 2005; Herwartz et al. 2011). This model of the alpine convergence of Adria with the European plate is in agreement with the plate-kinematic model proposed by Handy et al. (2010).

\subsection{The transverse, SW-verging Verzasca, Maggia,} Ziccher, Alpe Bosa and Wandfluhhorn F4 folds

Post-nappe transverse structures may be described as a succession of SW-verging F4 folds: the Verzasca anticline, Maggia syncline, Ziccher anticline, Alpe Bosa (F4a) and Wandfluhhorn (F4b) synclines (Figs. 2, 3, 6, 7, 8). The fold axis F4 developed parallel to the pre-existing XI stretching lineation of the top-to-NW directed nappe shearing. This development of folds parallel to an older stretching lineation is difficult to explain. Klaper (1988) according to
Cobbold and Watkinson (1981) suggested a mechanism in which the rheological bending anisotropy of a folded layer may control the orientation of younger fold axis. The topto-N shear indicators of the Verzasca anticline are rotated in its lower limb to a reversed top-to-S shear during folding (Allaz et al. 2005), whereas in the case of the Alpe Bosa and Wandfluhhorn NE-closing synclines, the top-to-NW shear indicators of the Antigorio gneiss in the Toce valley were rotated around the fold axis, resulting in a reversed top-to-E shear in the upper fold limb in the Bosco region. The staurolite of metapelites of the Bombogno, Campo Tencia and Sambuco units crystallises before and after the transverse F4 folding as also observed by Galli et al. (2007) (F3 in Galli et al.). There is no indication of an important retrograde greenschist facies crystallisation during this phase of deformation, as proposed by Merle et al. (1986, 1989). The amplitude of the transverse folds increases drastically from north to south with the increase of the metamorphic grade and rock ductility with depth. The large Cana F4-arch or vault of the Campo Tencia region develops southwards to the SW-verging Verzasca anticline exhibiting a style of similar folding (Figs. 3, 7). The several hundred metres amplitude of the Maggia transverse folds in the northern Sambuco spoon reaches over 5,000 m 
in the Someo region. The Ziccher and Alpe Bosa folds start to the north somewhere in the Bavona valley and the amplitude may be over $20 \mathrm{~km}$ north of the Melezzo and Melezza rivers (Valle Vigezzo and Centovalli) to the south. The axial traces of the Alpe Bosa and Wandfluhorn $\mathrm{N}$-closing backfolds overprint the older Antigorio fold and are not identical with the F2 axial trace of the Antigorio nappe as proposed by Maxelon and Mancktelow (2005). The geometry of the NW-directed isoclinal Antigorio fold nappe with its frontal autochthonous Mesozoic Teggiolo sedimentary cover is well exposed in the deeply eroded Cairasca and Devero valleys sections. The isoclinal Antigorio F2 fold with its root in the Toce valley is situated below the younger $25^{\circ} \mathrm{SE}$-dipping F4 axial surface of the Alpe Bosa fold (Fig. 2 and cross-section 3 on Fig. 3; Gerlach 1869, 1883; Milnes 1973; Steck 1984, 2008; Fig. 5). The transverse folds (F4) are in the southern steep belt overprinted by ductile dextral shear (Fig. 1). It is concluded that the transverse folding F4 predates the dextral shear and the S-directed backfolding F5 and rotation to vertical of the southern steep belt (Figs. 1, 2, 3, 7; Steck and Hunziker 1994; Steck 2008).

\subsubsection{The Wandfluhhorn double fold}

Schmidt and Preiswerk (1905), Grütter (1929), Preiswerk et al. (1934), Hunziker (1966) and Hall (1972) described the Wandfluhhorn fold. Klaper (1988), Steck and Hunziker (1994) and Steck (2008) interpreted it as a N-closing backfold. New observations by Franco Della Torre on map sheet Bosco/Gurin revealed a N-closing complex backfold structure created by two superposed backfolds. The older, Alpe Bosa F4a fold is deformed by the younger Wandfluhhorn F4b, also S-verging fold (Figs. 3, 6, 7).

\subsection{Dextral shear, S-verging folding F5, uplift}

of the Lepontine dome and formation

of the southern steep belt

The southern steep belt of the Central Alps between Locarno and Domodossola is overprinted by an up to $8 \mathrm{~km}$ wide ductile dextral shear zone formed under amphibolite facies conditions. The shear zone is folded after and during continuation of dextral shear by the Vanzone backfold F5, crosses to the west the Simplon pass and continues in the frontal part of the Siviez-Mischabel and Pontis nappes in the Rhone valley to the west of Visp. It is the dextral ductile Simplon shear zone (represented in blue colour on Fig. 1; Steck 1980, 1984, 1990, 2008; Steck and Hunziker 1994). Another branch of the ductile shear zone follows the southern border of the Monte Rosa nappe and continues in the low angle extensional shear zone of the Valtournanche (Vannay and Allemann 1990; Handy et al. 2005). The dextral and extensional Rhone-Simplon fault developed since $18 \mathrm{Ma}$ under brittle, and in its hot footwall, ductile conditions (represented in red colour on Fig. 1; Steck and Hunziker 1994) following the ductile extension on the older Simplon shear zone (represented in blue colour on Fig. 1). The older 34-18 Ma extensional structures of the ductile Simplon shear zone are hidden and no more distinguishable in the younger 18-3 Ma ductile structures of the Rhone-Simplon fault footwall (Figs. 1, 8; Steck and Hunziker 1994). Already Argand (1911, 1916) distinguished two phases of S-verging backfolding in the Monte Rosa massif that succeeded the NW-directed nappe emplacement. The younger phase is Argand's Insubric phase of backfolding. The root of the Vanzone backfold F5 is visible on Figs. 1, 2, 7. This SE-verging backfold was formed by a late conjugate movement opposite to the NWdirected Penninic and Helvetic thrusts (Steck 1984, 1990; Steck and Hunziker 1994; Escher and Beaumont 1997; Table 2). Its formation was accompanied by the uplift of the Lepontine dome since about 30-25 Ma (Hurford 1986; Hunziker et al. 1992; uplift (a) on cross-sections 2 and 3 of Fig. 3). Structural and petrological work shows that the Vanzone backfold was formed under amphibolite facies conditions after and during late dextral shear on the Simplon ductile shear zone (Table 2; Steck 1984; Steck and Hunziker 1994; Keller et al. 2005). This means that the southern steep belt and backfold F5 were created in a dextral shear zone of the Insubric line in the zone of continental collision.

\subsection{The Oligocene porphyrites (andesites), pegmatites,} aplites and migmatites

Porphyrites (andesitic dikes) are intruding the Canavese and Sesia zone along the Canavese fault. They are dated of 31-29 Ma (Steck and Hunziker 1994; Romer et al. 1996; Schärer et al. 1996; Table 2). They belong to the 33-29 Ma mantle-derived magmatism like the Bergell, Biella and Traversella granites and tonalites and Biella volcanic suite (Fig. 1; Beccaluva et al. 1983; Trommsdorff and Nievergelt 1983; Reusser 1987; Trommsdorff 1990; Romer et al. 1996; Berger et al. 2012; Kapferer et al. 2012). Muscovitebiotite pegmatites and aplites crosscut the southern steep belt between Valle d'Ossola and the Bergell. They are widespread in the Monte Rosa nappe and Orselina unit between the Valle d'Ossola and Locarno. They occur also in the Antrona and Zermatt-Saas ophiolites and more northern regions, the Monte Leone gneiss in the Valle dell'Isorno, the Pioda di Crana, Mergoscia, Maggia and Simano units (Stern 1966). They are the product of crustal melting and were dated by Romer et al. (1996) and Schärer et al. (1996) to 29-25 Ma. The ages are similar to the 32-22 Ma SHRIMP U-Pb zircon ages of two leucosome 
samples of Tertiary migmatites from the region of Bellinzona and Valle d'Arbedo (Rubatto et al. 2009; Fig. 8; Table 2). Tertiary migmatites are common in the southern steep belt between the entrance of the Onsernone valley to the west and the Bergell to east (Figs. 1, 2; Hänny et al. 1975). They occur often in Tertiary shear zones, where the Alpine age is undeniable. However, the distinction from the older Variscan migmatites of the polycyclic basement is difficult and the regional expansion of the zone of Tertiary migmatites is still a matter for debate (Stern 1966; Wenk 1970; Hänny et al. 1975; Romer et al. 1996; Schärer et al. 1996; Burri et al. 2005). Dextral shear in the southern steep belt occurred before, during and after the Oligocene intrusions (Table 2). The deep crustal melting was related to the formation of the dextral shear zone of the southern steep belt, as discussed by Schärer et al. (1996), Romer et al. (1996) and Rosenberg (2004). It is probable that the shear deformation supported fluid migration and supply, creating the high water pressure necessary for the Tertiary melting of pre-existing (dehydrated) Variscan migmatites, amphibolite facies metapelites and granitoides (Schärer et al. 1996; Burri et al. 2005; Rubatto et al. 2009).

\subsection{The Rhone-Simplon, Centovalli and Tonale faults}

The dextral and extensional Rhone-Simplon fault developed from 18 to 3 Mas under brittle, and in its hot footwall, ductile conditions, following the ductile extension on the older Simplon shear zone (Fig. 1, 8; Table 2; Steck and Hunziker 1994). The Vanzone back fold and the root of the Moncucco, Ruginenta, Camughera gneisses and the Antrona ophiolites are cut between Trontano, east of Domodossola and Druogno at an angle of up to $20^{\circ}$ by the anchizonal Centovalli fault (Fig. 2). The latter is parallel to the Orselina zone to the north. The Centovalli fault follows, between Santa Maria Maggiore and Intragna the northern contact of the Monte Rosa gneiss. Conjugate $\mathrm{W}$-directed dextral and $\mathrm{N}$-directed sinistral faults are associated with the dextral Centovalli fault and indicate NW-SE compression in a dextral zone of transpression (Figs. 2, 7; Wieland 1966; Matthias Tischler, personal communication; Steck 2008). Surace et al. (2011) dated the clay minerals of 9 fault gouges of the Centovalli line with the $\mathrm{K}-\mathrm{Ar}$ method of $14-4 \mathrm{Ma}$, completing the 9.1-8.3 Ma ages of Zwingmann and Mancktelow (2004). The Monte Rosa gneiss, Zermatt-Saas ophiolites, Sesia and Canavese zones are cut and end between Intragna and Locarno on W-NW-striking dextral faults. Also the Ivrea zone ends south of Locarno on the $\mathrm{W}$-striking dextral Tonale fault and forms there a $31-60^{\circ} \mathrm{NE}$-plunging, probably Tertiary F6 anticline. The disappearance of these zones must also be explained by a late uplift of southern blocks on these dextral faults (indicated as normal fault displacement b) on crosssections 2, 3 and 6 of Fig. 3).
4.6 The Ticino and Toce dome, late F6 folds and cooling history of the Lepontine dome

The amphibolite facies transverse folds and Vanzone backfold were overprinted during continuation of Alpine compression by younger open F6 folds, i.e. the greenschist facies Masera (Figs. 2, 7 and stereogram 5 on Fig. 6), Cristallina, Campo Tencia, Ticino, Toce, Someo, Vergeletto, Salmone (stereogram 6 on Fig. 6), Bordoglio and Finero F6 folds. The younger Masera F6 syncline was formed after cooling by uplift and erosion under greenschist facies conditions in contrast to the neighbouring and older amphibolite facies Vanzone F5 anticline (Steck 2008). The squeezing of F4-F6 folds in the southern steep belt is illustrated on Fig. 2 and the cross-sections 1 and 2 of Fig. 3. The Cristallina backfold is probably of a similar age as the Aar Massif-Glishorn backfold (Figs. 1, 2; Table 2) dated to about 10 Ma by Steck (1984), Steck and Hunziker (1994) and Campani (2011). It may be interpreted as a SWverging fold conjugate to the 9-4 Ma NW-directed Jura thrust (Table 2). The cooling history of the Lepontine gneiss dome and its Ticino and Toce culminations is constrained by radiometric data (Fig. 8; Hurford 1986; Hunziker 1969; Hunziker and Bearth 1969; Hunziker et al. 1992; Steck and Hunziker 1994; Liati et al. 2009; Rubatto et al. 2009; Garzanti and Malusà 2008). The cooling by uplift and erosion started after a temperature peak reached some 38-22 Ma ago. The 32-30 Ma Bergell tonalite to the east of the Lepontine gneiss dome intruded at depths of about $17 \mathrm{~km}$. It cooled to $300{ }^{\circ} \mathrm{C}$ some $28 \mathrm{Ma}$ ago by rapid uplift of about $7 \mathrm{~km}$ in $2 \mathrm{Ma}$ (uplift rate $\sim 3.5 \mathrm{~mm} / \mathrm{a}$ ) concomitant with erosion (Reusser 1987). The progressive cooling of the Lepontine area to temperatures below $500{ }^{\circ} \mathrm{C}$ some $38 \mathrm{Ma}$ ago is indicated by $\mathrm{Rb}-\mathrm{Sr}$ white mica ages on the eastern and western border of the dome structure. It is followed by the rapid cooling below $500{ }^{\circ} \mathrm{C}$ of the Verzasca anticline some $26 \mathrm{Ma}$ ago (Fig. 8; Hurford 1986) and an accelerated cooling of $50^{\circ} \mathrm{C} / \mathrm{Ma}$ of the Ticino culmination between 22 and $17 \mathrm{Ma}$ (Steck and Hunziker 1994; Rubatto et al. 2009). This was followed by the progressive cooling of the Toce culmination, farther west, characterised by phases of accelerated cooling of $37.5^{\circ} \mathrm{C} / \mathrm{Ma}$ between $18-15$ and $12-10 \mathrm{Ma}$ and of $40{ }^{\circ} \mathrm{C} / \mathrm{Ma}$ after $4 \mathrm{Ma}$. The latter cooling was related to the detachment on the brittle Rhone-Simplon low angle normal fault (Figs. 1, 8; Steck and Hunziker 1994; Campani 2011). The late cooling after $10 \mathrm{Ma}$ of the Ticino, Maggia and Toce valleys constrained by apatite FT ages is discussed by Garzanti and Malusà (2008). The en echelon position of the three crest lines F6 of the Ticino dome eroded by the Ticino River suggests a genetic relation between erosion and folding (Figs. 2, 7, 8). The direction of compression perpendicular to the fold axis is oblique to 
the Ticino River. The position of the Ticino dome and in a similar way the Toce dome controlled probably the erosion of the two transverse valleys. The interdependence of updoming and valley formation may be complex, as the rapid cooling by uplift and erosion of the dome structures started some $22 \mathrm{Ma}$ ago and was still active after the last Alpine glaciation, some 10,000 years ago.

\subsection{Late Alpine and active normal faults}

N-dipping late normal faults cut the Finero anticline (Steck and Tièche 1976). A late uplift of the Ivrea zone relative to the Sesia zone during the last $2 \mathrm{Ma}$ has been dated using the apatite fission track method (Yvon Fazis, personal communication).

The Guriner Furka and Hintere Furka faults, to the south of the Wandfluhhorn are active normal faults that displace the glacial landforms, testifying to a phase of late Alpine extension (Fig. 2; Table 2; Steck et al. 2001). Epidotechlorite-quartz veins in the Guriner Furka fault testify also to an older lower greenschist facies event.

\section{Discussion}

\subsection{Overall history of the study area}

The complex structures of the Central Alps result from the Tertiary southeast directed underthrust and collision of the European plate with the Adriatic plate indenter. The Helvetic nappes and the Lower-Middle Penninic basement fold nappes were formed by ductile detachment of the upper European crust, during its SE-directed underthrust below the upper Penninic and Austroalpine thrust sheets and the Adriatic plate. It is not possible to estimate the NW-SE shortening of the Alpine nappe stack because of material lost by erosion and subduction (Steck 2008). The style of deformation of the basement gneisses was controlled by their temperature-dependent rheology. It is suggested that the anchizone-greenschist facies limit, corresponding to a temperature of about $300{ }^{\circ} \mathrm{C}$, represents an important rheological boundary in the quartz-rich granitic European crust that determined the position of the frontal NW-verging Belledonne, Mont Blanc and Aar F2 basement folds (Steck 1968, 1984; Voll 1976). The en echelon position of the frontal folds was controlled by a slightly oblique direction of compression relative to the $300{ }^{\circ} \mathrm{C}$ isotherm trace (Fig. 1; Steck et al. 1989, 1999, 2001). The Rawil depression situated between the Mont Blanc and Aar en echelon basement folds, was overprinted by WNWoriented dextral strike-slip faults (e.g. Rezli fault zone, Gasser and Mancktelow 2010) during the younger, brittle, Rhone-Simplon fault deformation. The Lower Penninic
Antigorio, Simano and Maggia basement fold nappes accumulated by ductile shear on their frontal NW-verging F2 fold hinges their autochthonous Mesozoic sedimentary cover, the Teggiolo, Campolungo and Cristallina sedimentary covers, respectively. The high ductility of the amphibolite facies Lepontine gneisses deformed under temperatures of $550-650{ }^{\circ} \mathrm{C}$ allowed the younger formation, SW-directed overthrust and squeezing of the transverse Verzasca, Maggia, Ziccher, Alpe Bosa and Wandfluhhorn folds below the front of the west driving Adriatic indenter. Already Steck et al. (2001) and Maxelon and Mancktelow (2005) (Fig. 25 and 26) recognized the spectacular over $20 \mathrm{~km}$ amplitude of the Pioda di Crana basement backfold in the Antigorio nappe (Ziccher anticline on Figs. 2, 3, 7). It is however important to note that the axial traces of the F4a Alpe Bosa and F4b Wandfluhhorn north closing folds are not identical with the axial surface of the frontal NW-verging Antigorio F2 fold-nappe as proposed by Maxelon and Mancktelow (2005). The isoclinal NW-verging F2 fold geometry of the Antigorio recumbent fold nappe, with its frontal Mesozoic sedimentary cover, the Teggiolo zone, is undeniably preserved in the natural Valle Cairasca, Valle Devero and Simplon railway tunnel geological sections (Gerlach 1869, 1883; Schardt 1903; Schmidt and Preiswerk 1905; Milnes 1973, 1974; Steck 1984, 2008; Fig. 5; geological section on Fig. 3). The Pioda di Crana (Ziccher anticline) S-verging backfold is a younger east plunging F4 structure developed farther east on the upper limb of the pre-existing, NWverging Antigorio F2 fold nappe. It was formed during SW-directed overthrust of higher Penninic, Austroalpine and South Alpine units tangent to the Canavese fault in the southern root zone of the Central Alpine nappes.

\subsection{Importance of the Maggia transverse structure}

The most controversial question concerns the significance of the Sambuco-Maggia and Wandfluhhorn transverse structures. Is the Maggia transverse structure a syncline, as interpreted by Preiswerk (1921), Preiswerk et al. (1934); Niggli et al. 1936), Steck (1998, 2008) and Berger et al. (2005), or a root zone between a higher Simano nappe and the lower Antgorio nappe as discussed by Bossard in Preiswerk et al. (1934), Simpson (1982), Grujic and Mancktelow (1996), Maxelon and Mancktelow (2005) and Rütti et al. (2005)? The structural map (Fig. 2) and the cross-sections (Fig. 3) show that the Sambuco spoon and the Maggia syncline are two klippes of a single Maggia nappe which was situated on top of Mesozoic sediments in the case of the Sambuco spoon and on top of the deeper Mergoscia and Antigorio nappes to the west and the Cima Lunga and Simano nappes to the east. Berger et al. (2005) consider the Sambuco spoon and the Maggia syncline as 
two klippes, but the former belonging to the European and the latter to the Briançonnais domain. The affinity of the Mesozoic Cristallina cover of the Sambuco unit to the Helvetic sedimentary covers of the Gotthard and Mont Blanc massifs suggests that the Sambuco unit with its southern continuation in the Maggia unit belong together to the European domain.

The question of a Maggia root or a Maggia syncline is therefore still under discussion. It depends on Topic (A). The interpretation of the geological structures around $\mathrm{Fu}-$ sio, mapped by Keller et al. (1980) and Kröner (2000) and on Topic B) The geometry of the internal fold structures of the Maggia nappe.

Concerning A), it is to note that the Triassic to Cretaceous sediments of the Mogno syncline form an autochthonous contact with the staurolite-kyanite-garnet mica schist of the Campo Tencia unit. The $20^{\circ}-40^{\circ}$ southeast plunging axis indicate the antiformal geometry of the Mogno syncline (Figs. 2, 7). The twofold hinges of the antiformal syncline are also corroborated by the southern continuation of Triassic dolomite as two 50 and $60 \mathrm{~m}$ thick layers cut at depth at an altitude of $1,130 \mathrm{~m}$ and the Swiss map coordinates $(693.400 \mathrm{~km} / 141.900 \mathrm{~km}$ and $694.410 \mathrm{~km} / 141.480 \mathrm{~km}$ ) by the Valle di Prato-Camblee (Valle Maggia) water tunnel (unpublished data of E. Dal Vesco, reported by Franz Keller). The constructed fold axes of the northwestern antiform gives a value of $\geq 146 \%$ $\leq 28^{\circ}$ and of the southeastern antiform of $\geq 141^{\circ} / \leq 53$ and on the outcrop we measured an axis plunging at $35^{\circ}$ towards $133^{\circ}$ (Fig. 2; Fig. 3 in Steck 1998). This geometric feature confirms that the Mogno syncline is situated as an antiform in front and on top of the Simano nappe and below the Sambuco unit (cross-section 1 on Fig. 3; Steck 1998: Fig. 3) and cannot be identical with the synformal Piota syncline of the Valle Leventina at the base of the Simano unit, as postulated in the models of Grujic and Mancktelow (1996) and Maxelon and Mancktelow (2005). This geometric relation, between the Simano and Sambuco units corroborate the model of the overturned fold hinge at the Campolungo pass by Preiswerk (1919) ("Die überkippte Tauchfalte am Campolungopass...”). A large anticline, the Cana anticline (Figs. 2, 3), situated between the antiformal Mogno syncline, to the west, and the synformal Piota syncline, to the east, is responsible for the NW-directed overturning of the frontal Campolungo and Prevat F2 fold hinges (synformal anticlines) of the Simano nappe. The Sambuco unit is consequently situated to the north and on top of the deeper Simano nappe (geological profile 1 on Fig. 3). Other questions are still open:

(1) What is the structural relation between the Antigorio and Simano nappes? The cross-sections 4 and 5 on Fig. 3 and the cross-section $\mathrm{A}-\mathrm{A}^{\prime}$ on Figs. 1 and 8 illustrate the same tectonic position of the two nappes in the alpine nappe stack. But the two nappes are different in the composition of their basement gneisses and especially the different sedimentary cover sequences. The Teggiolo zone possesses a typical Helvetic sedimentary sequence, whereas the Triassic dolomites and the calc-schist of the Campolungo zone have a Penninic affinity (Table 1).

(2) The limit between the Maggia and Simano gneiss is defined by the decametre thick band of probable Triassic quartzite with centimetre (Upper Jurassic?) calcite-marble layers of the "Pertusio Zug", exposed from Monte Zucchero to the south, to east of Peccia to the north. The contact between the Mergoscia and Maggia units is identified between Someo and Brontallo by marble lenses of probable Upper Jurassic age of the Someo zone. The limit between the Maggia and Antigorio nappes between Brontallo and Peccia is not defined by Mesozoic sediments, and is thus uncertain.

Topic B) concerns the internal fold structures of the Maggia unit. Detailed mapping and analysis of the internal fold structures of the Maggia nappe indicate the geometry of a synclinal structure (cross-sections 4 and 5, Fig. 3). The F4 fold structures of the Valle di Coglio (Giumaglio)-Val d'Osura and Valle di Salto (Maggia) sections through the Maggia and Simano nappes illustrated by Steck (1998), Burri (2005) and unpublished structural data of the Maggia map sheet of the Geological Atlas 1:25,000 by Paul Gräter $(\dagger)$ are shown on the structural map (Fig. 2) and crosssections 4 and 5 on Fig. 3, as well as stereogram 2 on Fig. 6. The Maggia unit forms a big syncline, characterised by an alternation of second order F4 syn- and anticlines partly recognizable by the folded Cocco intrusion (Fig. 6, stereogram 2, and Fig. 7) Also the northern Sambuco spoon overlies as synformal anticline deeper Mesozoic sediments. The depth of the Maggia syncline hinge is unknown and roughly estimated to be about $5 \mathrm{~km}$ to the east of Someo and Maggia (Fig. 3, sections 1, 4 and 5, and Fig. 8, section A-A'). The petrological similarity, and the same late Carboniferous age, of the Matorello and Cocco granitoids are in agreement with the model that the Sambuco spoon and the Maggia syncline are two klippes of the same Maggia nappe (Bussien et al. 2011). It is suggested that the SW-verging F4 transverse Sambuco-Maggia fold forms, together with the frontal, NW-verging F2-F3 folds of the Antigorio and Simano folds, a type twofold interference pattern after the definition of fold interference structures by Ramsay (1967) (Fig. 2). Such F2-F3/F4 fold interference patterns are common in the region of Sambuco and Fusio. The bend of the F4 fold axis plunging from $45^{\circ}$ east to $30^{\circ}$ south in the southern Sambuco unit near Fusio could be explained by this fold interference pattern. It is also possible that, in the Sambuco unit, the F4 fold developed parallel to the pre-existing F2 or F3 fold hinges, especially in the north-western part of the Sambuco klippe 
(Galli et al. 2007) and that the rheological bending anisotropy of the folded layer controlled the orientation of the younger fold axis (Cobbold and Watkinson 1981).

The Lepontine gneiss dome, limited to the southwest by the ductile Simplon shear zone and the younger RhoneSimplon fault, from the Dent Blanche depression, represent together a late pull-apart structure in a zone of dextral transpression in front of the Adriatic indenter (Fig. 1; Table 2). The total amount of SW-directed dextral translation of the Adriatic indenter against the European Plate, estimated of over $100 \mathrm{~km}$ corresponds to the sum of displacements by the SW-verging Verzasca, Maggia, Ziccher and Alpe Bosa and Wandfluhorn folds measured of about $30 \mathrm{~km}$, the SW-extension of over $60 \mathrm{~km}$ on the ductile Simplon shear zone and the detachment of about $14 \mathrm{~km}$ on the Rhone-Simplon low angle normal fault (Steck 1984, 1990, 2008; Mancktelow 1985, 1990; Steck and Hunziker 1994). The cooling history of the Lepontin gneiss dome and its Ticino and Toce culminations since 38-22 Ma is demonstrated by radiometric cooling ages by Steck and Hunziker (1994; Hurford 1986; Hunziker et al. 1992; Rubatto et al. 2009; Fig. 8). The lack of some nappe roots in the southern steep belt of the Lepontine gneiss dome is a problematic feature of the Central Alps. This disappearance can be explained by normal fault removal on the late Alpine Centovalli and Tonale faults and the covering by the Pioda di Crana unit and Bosco-Bombogno-IsornoOrselina zone of the Ziccher recumbent fold. The structural map of the Lepontine Alps and cross-sections (Figs. 2, 3) represent an updated model of the complex fold interference pattern of the deepest tectonic level of the Alpine nappe stack. This model has to be considered as a basis for discussion and future fieldwork.

Acknowledgments Guido Schreuers and Andrea Zanchi are thanked for their critical reviews, Yves Gouffon for his careful corrections, and Geoffrey Milnes for the editorial handling of the manuscript. Thomas Burri, Alberto Colombi, Jean-Luc Epard, Neil Mancktelow and Stefan Schmalholz are thanked for their fruitful discussions on the outcrop and in the laboratory. Thanks are due to Jean-Yves Délèzes and Florence Lodetti for the use of material from their work in the Cristallina and Lago di Naret areas, and Stefan Kröner in the Fusio area (MSc theses, Lausanne University). We also wish to thank, Matthias Tischler, Stefan Schmid and André Zingg, who provided unpublished field guide documents of the Valle Vigezzo region, and Gianreto Manatschal, of the Austroalpine nappes of eastern Switzerland.

\section{References}

Allaz, J., Maeder, X., Vannay, J.-C., \& Steck, A. (2005). Formation of alumosilicate-bearing quartz veins in the Simano nappe (central Alps): structural, thermobarometric and oxygen isotope constraints. Schweizerische Mineralogische und Petrographische Mitteilungen, 85(2-3), 191-214.
Amato, J. M., Johnson, C. M., Baumgartner, L. P., \& Beard, B. L. (1999). Rapid exhumation of the Zermatt-Saas ophiolite deduced from high precision $\mathrm{Sm}-\mathrm{Nd}$ and $\mathrm{Rb}-\mathrm{Sr}$ geochronology. Earth and Planetary Science Letters, 171, 425-438.

Argand, E. (1911). Les nappes de recouvrement des Alpes Pennines et leurs prolongements structuraux. Beiträge zur Geologischen Karte der schweiz [N.F.] 31, 26.

Argand, E. (1916). Sur l'arc des Alpes Occidentales. Eclogae Geologicae Helvetiae, 14, 145-204.

Babist, J., Handy, M., Konrad-Schmolke, M., \& Hammerschmidt, K. (2007). Precollisional, multistage exhumation of subducted continental crust: The Sesia Zone, western Alps. Tectonics, 25. doi:10.1029/2005TC001927.

Baechlin, R., Bianconi, F., Codoni, A., Dal Vesco, E., Knoblauch, P., Kündig, E., Reinhard, M., Spaenhauer, F., Spicher, A., Trommsdorff, V., \& Wenk, E. (1974). Blatt 1313 Bellinzona, Nr. 66. In Geologischer Atlas der Schweiz 1:25'000, 1313 Bellinzona. Schweizerische Geologische Kommission, Basel.

Bagnoud, A., Wernli, R., \& Sartori, M. (1998). Découverte de foraminifères planctoniques paléogènes dans la zone de SionCourmayeur à Sion (Valais, Suisse). Eclogae geologicae Helvetiae, 91/3, 421-329.

Bearth, P. (1952). Geologie und Petrograhie des Monte Rosa. Beiträge zur Geologischen Karte der Schweiz [N.F.], 96, 94.

Bearth, P. (1967). Die Ophiolote der Zone von Zermatt-Saas Fee. Beiträge zur Geologischen Karte der Schweiz [N.F.] 132, 130.

Bearth, P. (1973). Gesteins- und Mineralparagenesen aus den Ophioliten von Zermatt. Schweizerische Mineralogische und Petrographische Mitteilungen, 53(2), 299-334.

Beccaluva, L., Bigioggero, B., Chiesa, S., Colombo, A., Gatto, G. O., Gregnanin, A., et al. (1983). Post collisional orogenic dike magmatism in the Alps. Memorie Societa Geologica Italia, 26, 341-359.

Becker, H. (1993). Garnet peridotite and eclogite Sm-Nd mineral ages from the Lepontine dome (Swiss Alps): new evidence for Eocene high-pressure metamorphism in the central Alps. Geology, 21, 599-602.

Berger, A. \& Mercolli, I. (2006). Tectonic and Petrographic Map of the central Lepontine Alps. Carta geologica speciale N., 1:100,000 (Vol. 127). Wabern: Office fédérale de topographie.

Berger, A., Mercolli, I., \& Engi, M. (2005). The Central Lepontine Alps: explanatory notes accompaning the tectonic-geological map sheet Sopra Ceneri $(1: 100,000)$. Schweizerische Mineralogische und Petrographische Mitteilungen, 85, 109-146.

Berger, A., Thompson, T. B., Ovtcharova, M., Kapferer, N., \& Mercolli, I. (2012). Dating emplacement and evolution of the orogenic magmatism in the internal Western Alps: 1. The Miagliano Pluton. Swiss Journal of Geosciences, 105, 49-65.

Bergomi, M. A., Tunesi, A., Shi, Y.-R., Colombi, A. \& Liu D.-Y. (2007). SHRIMP II U/Pb geochronological constraints of preAlpine magmatism in the Lower Penninic Units of the Ossola Valley (Western Alps, Italy), Geophysical Research Abstracts, 9, 07780, European Geosciences Union.

Bernoulli, D., Manatschal, G., Desmurs, L., \& Müntener, O. (2003) Where did Gustav Steinmann see the trinity? Back to the roots of an Alpine ophiolite concept. Geological Society of America Special Paper, 373, 93-110.

Bianconi, F. (1971). Geologia e petrografia delle regione del Campolungo. Materiali per la Carte Geologica della Svizzera N.S. 142, 238.

Bigioggero, B., Boriani, A., Colombo, A., Ferrara, G., Tunesi, A., \& Tonarini, S. (1981a). Eta e caratteri petrochimici degli ortogneiss della zona Moncucco-Orselina nell'area Ossolana. Rendiconti della Societa Italiana di Mineralogia e Petrologia, 38, 207-218.

Bigioggero, B., Boriani, A., Colombo, A. \& Gregnanin, A. (1981). Carta geologica delle Valli Vigezzo, Fenecchio e basso Isorno. 
1:25 000. C.N.R.-Centro di studio per la stratigrafia e petrografia delle Alpi centrali - Milano. S.E.L.CA., Firenze.

Bill, M., Bussy, F., Cosca, M., Masson, H., \& Hunziker, J. C. (1997). High precision $\mathrm{U}-\mathrm{Pb}$ and ${ }^{40} \mathrm{Ar} /{ }^{39} \mathrm{Ar}$ dating of an Alpine ophiolite (Gets nappe, French Alps). Eclogae Geologicae Helvetiae, 90, 43-54.

Bill, M., O’Dogherty, L., Guex, J., Baumgartner, P. O., \& Masson, H. (2001). Radiolarite ages in Alpine-Mediterranean ophiolites: constraints on the oceanic spreeding and the Tethys-Atlantic connexion. Geological Society of America Bulletin, 113(1), 129-143.

Bousquet, R., Goffé, B., Vidal, O., Oberhansli, R., \& Patriat, M. (2002). The tectonometamorphic history of the Valaisan domain from the Western Alps to the Central Alps: new constaints on the evolution of the Alps. Geological Society of America Bulletin, 114, 207-225.

Brouwer, F. M., Burri, T., Engi, M., \& Berger, A. (2005). Eclogite relicts in the Central Alps: Pt-evolution, Lu-Hf ages and implications for formation of tectonic mélange zones. Schweizerische Mineralogische und Petrographische Mitteilungen, 85, 147-174.

Burckhardt, C. E. (1942). Geologie und Petrographie des BasodinoGebietes (Nordwestliches Tessin). Schweizerische Mineralogische und Petrographische Mitteilungen, 22, 99-188.

Burckhardt, C. E. \& Günthert, A. (1957). Blatt 1271 Basodino Nr. 34. In Geologischer Atlas der Schweiz, 1:25,000.

Burri, T. (2005). From high-pressure to migmatisation: on orogenic evolution of the southern Lepontine (central Alps of Switzerland/Italy). Ph.D. dissertation, Bern University.

Burri, T., Berger, A., \& Engi, M. (2005). Tertiary migmatites in the Central Alps: regional distribution, field relations, conditions of formation, and tectonic implications. Schweizerische Mineralogische und Petrographische Mitteilungen, 85, 215-232.

Bussien, D., Bussy, F., Magna, T., \& Masson, H. (2011). Timing of Paleozoic magmatism in the Maggia and Sambuco nappes and paleogeographic implications (central Lepontine Alps). Swiss Journal of Geosciences, 104, 1-29.

Bussy, F., Venturini, G., Hunziker, J., \& Martinotti, G. (1998). U-Pb ages of magmatic rocks of the western Austroalpine DentBlanche-Sesia unit. Schweizerische Mineralogische und Petrographische Mitteilungen, 78(1), 163-168.

Campani, M. (2011). Temporal and spatial evolution of a synorogenic extensional system: the Simplon Fault Zone (Central Alps). Ph.D. dissertation No 18461, ETH Zürich.

Carrupt, E. (2002). Geological and mineralogical study of the High Val Formazza - Binntal area (Central Alps). Ph.D. dissertation, Lausanne University.

Casasopra, S. (1939). Studio petrographico dello Gneiss granitico Leventina. Schweizerische Mineralogische und Petrographische Mitteilungen, 19, 449-710.

Chatterjee, N. D. (1961). The Alpine metamorphism in the Simplon area, Switzerland and Italy. Geologische Rundschau, 51, 1-72.

Cobbold, P. R., \& Watkinson, A. J. (1981). Bending anisotropy: a mechanical constraint on the orientation of fold axes in an anisotropic medium. Tectonophysics, 72, T1-T10.

Colombi, A. (1989). Métamorphisme et géochimie des roches mafiques des Alpes ouest-centrales (géoprofil Viège - Domodossola - Locarno). Mémoires de géologie (Lausanne) 4.

Dal Piaz, G. V., Cortiana, G., Del Moro, A., Martin, S., Pennacchioni, G., \& Tartarotti, P. (2001). Tertiary age and paleostructural inferences of the eclogitic imprint in the Austroalpine outliers and Zermatt-Saas ophiolite, western Alps. International Journal of Earth Sciences, 90, 668-684.

Duchêne, S., Blichert-Toft, J., Luais, B., Télouk, P., Lardaux, J. M., \& Albarède, F. (1997). The Lu-Hf dating of garnets and the ages of the Alpine high-pressure metamorphism. Nature, 387, 586-588.
Engi, M., Berger, A., \& Roselle, G. (2001a). The role of the tectonic accretionary channel in collisional orogeny. Geology, 29, $1143-1146$.

Engi, M., Scherrer, N. C., \& Burri, T. (2001b). Metamorphic evolution of pelitic rocks of the Monte Rosa nappe: constraints from petrology and single grain monazite age data. Schweizerische Mineralogische und Petrographische Mitteilungen, 81, 305-328.

Engi, M., Berger, A. \& Roselle, G. (2001). The role of the tectonic accretionary channel in collisional orogeny. Geology, 29, $1143-1146$.

Engi, M., Todd, C. S., \& Schmatz, D. R. (1995). Tertiary metamorphic conditions in the eastern Lepontine Alps. Schweizerische Mineralogische und Petrographische Mitteilungen, 75, 347-369.

Epard, J.-L., \& Escher, A. (1996). Transition from basement to cover: a geometric model. Journal of Structural Geology, 18, 533-548.

Escher, A., \& Beaumont, C. (1997). Formation, burial and exhumation of basement nappes at crustal scale: a geometric model based on the western Swiss-Italian Alps. Journal of Structural Geology, 19, 955-974.

Escher, A., Hunziker, J., Marthaler, M., Masson, H., Sartori, M. \& Steck, A. (1997). Geologic framework and structural evolution of the western Swiss-Italian Alps. In: Pfiffner, O.A., Lehner, P., Heitzmann, P., Mueller, S. \& Steck, A. (Eds.), Deep structure of the Swiss Alps: Results of NRP (Vol. 20, pp. 205-221). Basel: Birkhäuser.

Escher, A., Masson, H., \& Steck, A. (1993). Nappe geometry in the Western Swiss Alps. Journal of Structural Geology, 15, 501-509.

Ferrando, S., Bernoulli, D., \& Compagnoni, R. (2004). The Canavese zone (internal Western Alps): a distal margin of Adria. Schweizerische Mineralogische und Petrographische Mitteilungen, 84, 237-256.

Frank, E. (1983). Alpine metamorphism of calcareous rocks along a cross-section in the Central Alps: occurence and breakdown of muscovite, margarite and paragonite. Schweizerische Mineralogische und Petrographische Mitteilungen, 63, 37-93.

Frey, M. Desmons, J. \& Neubauer, F. (1999). The new metamorphic map of the Alps. Schweizerische Mineralogische und Petrographische Mitteilungen 79, 89-110.

Galli, A., Mancktelow, N., Reusser, E., \& Caddick, M. (2007). Structural geology and petrography of the Naret region (northern Valle Maggia, N. Ticino, Switzerland). Swiss Journal of Geosciences, 100, 53-70.

Galster, F., Cavargna-Sani, M., Epard, J.-L., \& Masson, H. (2012). New stratigraphic data from the Lower Penninic between the Adula nappe and the Gotthard massif and consequences for the tectonics and the paleogeography of the Central Alps. Tectonophysics, 579, 37-55.

Galster, F., Epard, J.-L., \& Masson, H. (2010). The Soja and LuzzoneTerri nappes: discovery of a Briançonnais element below the front of the Adula nappe (NE Ticino, Central Alps). Bulletin Société vaudoise des Sciences naturelles, 92(2), 61-75.

Garzanti, E., \& Malusà, M. G. (2008). The Oligocene Alps: domal unroofing and drainage development during early orogenic growth. Earth and Planetary Science Letters, 268, 487-500.

Gasser, D., \& Mancktelow, N. S. (2010). Brittle faulting in the Rawil depression: field observations from the Rezli fault zone, Helvetic nappes, Western Switzerland. Swiss Journal of Geosciences, $103,15-32$.

Gebauer, D. (1999). Alpine Geochronology of the central and Western Alps. Schweizerische Mineralogische und Petrographische Mitteilungen, 79, 191-208.

Genier, F., Epard, J. L., Bussy, F., \& Magna, T. (2008). Lithostratigraphy and $\mathrm{U}-\mathrm{Pb}$ zircon dating in the overturned limb of the Siviez-Mischabel nappe; a new key for middle Penninic nappe geometry. Swiss Journal of Geosciences, 101, 431-452. 
Geologische Karte der schweiz, 1:500'000 (2005). Federal Office for Water and Geology. Bern, Switzerland.

Gerlach, H. (1869). Die Penninischen Alpen. Beiträge zur Geologischen Karte der Schweiz, 23/1.

Gerlach, H. (1883). 1. Heinrich Gerlach, sein Leben und Wirken. 2. Die Penninischen Alpen. 3. Bericht über den Bergbau im Kanton Wallis. Beiträge zur Geologischen Karte der Schweiz [N.F.] 27, 1-79.

Grujic, D., \& Mancktelow, N. S. (1996). Structure of the northern Maggia and Lebendun nappes, Central Alps, Switzerland. Eclogae Geologicae Helvetiae, 89, 461-504.

Grütter, O. (1929). Petrographische und geologische Untersuchungen in der Region von Bosco (Valle Maggia). Verhandlungen der Naturforschenden Gesellschaft in Basel Band XL, Birkhäuser: Tessin.

Hall, W. D. M. (1972). The structural and metamorphic history of the lower Pennine nappes, Valle di Bosco, Ticino, Switzerland. Ph.D. dissertation, University of London.

Hammerschmidt, K., \& Frank, E. (1991). Relics of high pressure metamorphism in the Lepontine Alps (Switzerland)-40Ar/39Ar and microprobe analyses on white K-micas. Schweizerische Mineralogische und Petrographische Mitteilungen, 71, 261-274.

Handy, M. R., Babist, J., Wagner, R., Rosenberg, C. \& Konrad, M. (2005). Decoupling and its relation to strain partitioning in continental lithosphere: insight from the Periadriatic fault system (European Alps). In: D. Gapais, J.P. Brun \& P.R. Cobbold (Eds.), Deformation mechanism, rheology and tectonics: from minerals to the lithosphere. Geological Society of London, Special Publications, 243, 249-276.

Handy, M. R., Franz, L., Heller, F., Janott, B., \& Zurbriggen, R. (1999). Multistage exhumation and accretion of the continental crust (Ivrea crustal section, Italy and Switzerland). Tectonics, 18, 1154-1177.

Handy, M. R., Schmid, S. M., Bousquet, R., Kissling, E., \& Bernoulli, D. (2010). Reconciliation plate-tectonic reconstructions of Alpine Tethys with the geological-geophysical record of spreadind and subduction in the Alps. Earth-Science Reviews, 102, 121-158.

Handy, M. R., \& Zingg, A. (1991). The tectonic and rheologic evolution of an attenuated cross-section of the continental crust: ivrea crustal section, southern Alps, northwestern Italy and southern Switzerland. Geological Society of America Bulletin, $103,236-253$

Hänny, R., Grauert, B., \& Soptrajanova, G. (1975). Paleozoic migmatites affected by high-grade tertiary metamorphism in the Central Alps (Valle Bodengo, Italy). Contribution to Mineralogy and Petrology, 51, 173-196.

Hasler, P. (1949). Geologie und Petrographie der Sambuco-MassariGebirgsgruppe zwischen der oberen Valle Leventina und Valle Maggia im nördlichen Tessin. Schweizerische Mineralogische und Petrographische Mitteilungen, 29, 50-155.

Henk, A., Franz, L., Teufel, S., \& Oncken, O. (1997). Magmatic underplatting, extension and crustal re-equilibration: insights from a cross-section through the Ivrea Zone and Strona-Ceneri Zone, Northern Italy. Journal of Geology, 105(3), 367-377.

Herwartz, D., Nagel, T. J., Münker, C., Scherer, E. E., \& Froitzheim, N. (2011). Tracing two orogenic cycles in one eclogite sample by Lu-Hf garnet chronometry. Nature Geoscience, 4, 178-183.

Herwegh, M., \& Pfiffner, O. A. (2005). Tectonometamorphic evolution of a nappe stack: a case study of the Swiss Alps. Tectonophysics, 404, 55-76.

Huber, M. L. (1981). Geologisch-strukturelle Untersuchungen im Oberen Maggiagebiet (Tessin, Schweiz). Ph.D. dissertation, ETH Zürich (221 p.).

Huber, M. L., Ramsay, J., \& Simpson, C. (1980). Deformation in the Maggia and Antigorio nappes, Lepontine Alps. Eclogae Geologicae Helvetiae, 73, 593-606.
Hunziker, J. C. (1966). Zur Geologie und Geochemie des Gebietes zwischen Valle Antigorio (Provincia di Novara) und Valle di Campo (Kt. Tessin). Schweizerische Mineralogische und Petrographische Mitteilungen, 46, 473-552.

Hunziker, J. C. (1969). Rb/Sr Altersbestimmungen aus den Wallisser Alpen, Hellglimmer und Gesammtgesteinswerte. Eclogae Geologicae Helvetiae, 62, 527-542.

Hunziker, J. C., \& Bearth, P. (1969). Rb-Sr-Altersbestimmungen aus den Wallisser Alpen, Biotitalterswerte und ihre Bedeutung für die Abkühlungsgeschichte der alpinen Metamorphose. Eclogae Geologicae Helvetiae, 62, 205-222.

Hunziker, J. C., Desmons, J. \& Hurford, A. J. (1992). Thirty-two years of geochronological work in the central and Western Alps: a review on seven maps. Mémoires de géologie (Lausanne), 13, $1-59$.

Hurford, A. J. (1986). Cooling and uplift patterns in the Lepontine Alps, south-central Switzerland, and an age of vertical movement on the Insubric fault line. Contributions to Mineralogy and Petrology, 93, 413-427.

Joos, M. G. (1969). Zur Geologie und Petrographie der Monte GioveGebirgsgruppe im östlichen Simplon-Gebiet (Novara, Italia). Schweizerische Mineralogische und Petrographische Mitteilungen, 49, 277-323.

Kapferer, N., Mercolli, I., Berger, A., Ovtcharova, M., \& Fügenschuh, B. (2012). Dating emplacement and evolution of the orogenic magmatism in the the internal Western Alps: 2. The Biella Volcanic Suite. Swiss Journal of Geosciences, 105, 67-84.

Keller, F. (1968). Mineralparagenesen und Geologie der Campo Tencia-Pizzo Forno-Gebirgsgruppe. Beiträge zur Geologischen Karte der Schweiz [N.F.], 135, 71 p.

Keller, L. M., Hess, M., Fügenschuh, B., \& Schmid, S. M. (2005). Structural and metamorphic evolution SW of the Simplon line. Eclogae Geologicae Helvetiae, 98, 19-49.

Keller, F., Wenk, E., Bianconi, F. \& Hasler, P. (1980). Blatt 1272 P. Campo Tencia. In Geologischer Atlas der Schweiz 1: 25,000, Atlasblatt, 73.

Klaper, E. (1988). Quartz c-fabric development and large-scale postnappe folding (Wandfluhhorn Fold, Penninic Alps). Journal of Structural Geology, 10(8), 795-802.

Knup, P. (1958). Geologie und Petrographie des Gebietes zwischen Centovalli-Valle Vigezzo und Onsernone. Schweizerische Mineralogische und Petrographische Mitteilungen, 38, 83-236.

Kobe, H. W. (1956). Geologisch-petrographische Untersuchungen in der Tessiner Wurzelzone zwischen Vergeletto-Onsernone und Valle Maggia. Schweizerische Mineralogische und Petrographische Mitteilungen, 36, 234-284.

Konrad-Schmolke, M., Babist, J., Handy, M. R., \& O’Brian, P. J. (2006). The physico-chemical properties of a subducted slab from garnet zontion patterns (Sesia zone, Western Alps). Journal of Petrology, 47, 2123-2148.

Köppel, V., Günthert, A. \& Grünefelder, M. (1981). Patterns of U-Pb zircon and monazite ages in polymetamorphic units of the Swiss Alps. Schweizerische Mineralogische und Petrographische Mitteilungen, 61, 97-119.

Kröner S. (2000). Analyse minéralogique et tectonique dans la region Fusio- Valle Maggia (Tessin, Suisse). Master dissertation, Université de Lausanne.

Lapen, B. J., Johnson, C. M., Baumgartner, L. P., Mahlen, N. J., Beard, B. L., \& Amato, J. M. (2003). Burial rates during prograde metamorphism of an ultra-high-pressure terrane: an example from Lago di Cignana, Western Alps, Italy. Earth Planetary Science Letters, 215, 57-72.

Liati, A., Froitzheim, N., \& Fanning, C. M. (2005). Jurassic ophiolites within the Valais domain of the Western and central Alps: geochronological evidence for re-rifting of oceanic crust. Contribution to Mineralogy and Petrology, 149, 446-461. 
Liati, A., Gebauer, D., \& Fanning, M. (2009). Geochronological evolution of HP metamorphic rocks of the Adula nappe, Central Alps, in pre-Alpine and Alpine subducting cycles. Journal of the Geological Society, London, 166, 797-810.

Mancktelow, N. S. (1985). The Simplon Line: a major displacement zone in the Western Lepontine Alps. Eclogae Geologicae Helvetiae, 78, 73-96.

Mancktelow, N. S. (1990). The Simplon Fault Zone. Beiträge zur Geologischen Karte der Schweiz. [N.F.], 163, 74.

Markley, M. J., Teyssier, C., Cosca, M. A., Caby, M. A., Hunziker, J. C., \& Sartori, M. (1998). Alpine deformation and ${ }^{40} \mathrm{Ar} /{ }^{39} \mathrm{Ar}$ geochronology of synkinematic white mica in the SiviezMischabel Nappe, western Pennine Alps, Switzerland. Tectonics, $17,407-425$.

Masson, H. (2002). Ophiolites and other (ultra) basic rocks from the West-Central Alps: new data for a puzzle. Bulletin de la Société Vaudoise des Sciences Naturelles 88, 263-276.

Matasci, B., Epard, J.-L., \& Masson, H. (2011). The Teggiolo zone: a key to the Helvetic - Penninic connection (stratigraphy and tectonics in the Val Bavona, Ticino, Central Alps). Swiss Journal of Geosciences, 104, 257-284.

Maxelon, M., \& Mancktelow, N. S. (2005). Three-dimensional geometry and tectonostratigraphy of the Pennine zone, Central Alps, Switzerland and Northern Italy. Earth-Sciences Reviews, $71,171-227$.

Merle, O., Cobbold, P. R., \& Schmid, S. (1989). Tertiary kinematics in the Lepontine dome. In: M.P. Coward, D. Dietrich \& R.G. Park (Eds.). Alpine tectonics. Geological Society Special Publication, 45, 113-134.

Merle, O., Le Gal, P., \& Mancel, P. (1986). Déformation et métamorphisme dans la région du Simplon (Alpes centrales). Eclogae Geologicae Helvetiae, 79, 705-718.

Milnes, A. G. (1973). Structural re-interpretation of the classic Simplon tunnel section of the Central Alps. Bulletin Geological Society America, 84, 269-274.

Milnes, A. G. (1974). Post-nappe folding in the western Lepontine Alps. Eclogae Geologicae Helvetiae, 67, 333-348.

Milnes, A. G. (1975). On steep Isogradic surfaces in the simplon area: a discussion. Contribution to Mineralogy and Petrology, 53, $65-68$.

Milnes, A. G., Greller, M., \& Müller, R. (1981). Sequence and style of major post- nappe structures, Simplon-Pennine Alps. Journal of structural Geology, 3(4), 411-420.

Niggli, P., Preiswerk, H., Grütter, O., Bossard, L., Kündig, E. (1936). Geologische Beschreibung der Tessiner Alpen zwischen Maggia- und Bleniotal. Beiträge zur Geologischen Karte der Schweiz N.F., 71 .

Oberhänsli, R. (Ed.) (2004). Metamorphic structure of the Alps, Explanatory notes and map, Scale 1:1000000. Mitteilungen der Österreichischen Mineralogischen Gesellschaft, 149, 115-226.

Pawlig, S., \& Baumgartner, L. (2001). Geochemistry of a talckyanite-chloritoid shear zone within the Monte Rosa granite, Val d'Ayas, Italy. Schweizerische Mineralogische und Petrographische Mitteilungen, 81, 329-346.

Pfeifer, H.-R., Colombi, A., Ganguin, J., Hunziker, J. C., Oberhänsli, R., \& Santini, L. (1991). Relicts of high-pressure metamorphism in different lithologies of the Central Alps, an updated inventory. Schweizerische Mineralogische und Petrographische Mitteilungen, 71, 441-451.

Preiswerk, H. (1919). Die überkippte Tauchfalte am Campolungopass und ihre früheren Deutungen. "Heim-Festschrift". Vierteljahresschrift Naturforschende Gesellschaft Zürich, LXIV, $1-15$.

Preiswerk, H. (1921). Die zwei Deckenkulminationen Tosa-Tessin und die Tessinerquerfalte. Eclogae Geologicae Helvetiae, 16, 485-496.
Preiswerk, H., Bossard, L., Grütter, O., Niggli, P., Kündig, E., Ambühl, E. et al. (1934). Geologische Karte der Tessineralpen zwischen Maggia- und Bleniotal. Geologische Spezialkarte Nr. 116. Bern: Schweizerische Geologische Kommission.

Ramsey, J. (1967). Folding and fracturing of rocks. London: McGraw-Hill.

Reinecke, T. (1998). Prograde high- to ultrahigh-pressure metamorphism and exhumation of oceanic sediments at Lago Cignana, Zermatt-Saas Zone, Western Alps. Lithos 42, 147-189.

Reinhardt, B. (1966). Monte Rosa-Zone, Sesia-Zone und Canavese im Gebiet zwischen Valle d'Ossola und Valle Loana (Prov. Novara). Schweizerische Mineralogische und Petrographische Mitteilungen, 46, 553-678.

Reusser, E. (1987). Phasenbeziehungen im Tonalit der Bergeller Intrusion. Ph.D. dissertation, ETH Zürich 8329.

Rodgers, J., \& Bearth, P. (1960). Zum Problem der Lebendundecke. Eclogae Geologicae Helvetiae, 53(1), 169-178.

Romer, R., Schärer, U., \& Steck, A. (1996). Alpine and pre-Alpine magmatism in the root zone of the Western Alps. Contribution to Mineralogy and Petrology, 123, 138-158.

Rosenberg, C. L. (2004). Shear zones and magma ascent: A model based on a review of the Tertiary magmatism in the Alps. Tectonics 23, tc3002. doi:10.1029/2003tc001526.

Rubatto, D., Gebauer, D., \& Fanning, M. (1998). Jurassic and Eocene subduction of the Zermatt-Saas-Fee ophiolites: implications for the geodynanic evolution of the Central and Western Alps. Contribution to Mineralogy and Petrology, 132, 269-287.

Rubatto, D., Herrmann, J., Berger, A., \& Engi, M. (2009). Protracted fluid-induced melting during Barrovian metamorphism in the Central Alps. Contributions to Mineralogy and Petrology, 158, 703-722.

Ruffet, G., Gruau, G., Ballèvre, Mm., Féraud, G. \& Philippot, P. (1997). Rb-Sr und 40Ar-39Ar laser probe dating of high-pressure phengites from the Sesia zone (Western Alps): underscoring of excess argon and new age constraints on the high-pressure metamorphism. Chemical Geology, 141, 1-18.

Rütti, R., Maxelon, M., \& Mancktelow, N. S. (2005). Structure and kinematics of the northern Simano nappe, Central Alps, Switzerland. Eclogae Geologicae Helvetiae, 98, 63-81.

Sartori, M. (1987). Structures de la zone du Combin entre les Diablons et Zermatt (Valais). Eclogae Geologicae Helvetiae, 80(3), 789-814.

Sartori, M., Gouffon, Y., Marthaler M. (2006). Lithostratigraphie des unités briançonnaises en Valais. Swiss Journal of Geosciences, 99(3), 363-408.

Schardt, H. (1903). Note sur le profil géologique et la tectonique du massif du Simplon comparés aux travaux antérieurs. Eclogae Geologicae Helvetiae, 8, 173-200.

Schärer, U., Cosca, M., Steck, A., \& Hunziker, J. (1996). Termination of major ductile strike-slip shear and differential cooling along the Insubric line (Central Alps). Earth and Planetary Science Letters, 142, 331-351.

Schmid, S., Fügenschuh, B., Kissling, E., \& Scuster, R. (2004). Tectonic map of the Alps. Eclogae Geologicae Helvetiae, 97, 93-117.

Schmid, S., Aebli, H. R. Heller, F. \& Zingg, A. (1989). The role of the Periadriatic Line in the tectonic evolution of the Alps. In M.P. Coward, D. Dietrich \& R.G. Park (Eds.), Alpine tectonics (Vol. 45, pp. 153-171). London: Geological society of London special Publication.

Schmidt, C. \& Preiswerk, H. (1905). Geologische Karte der Simplongruppe. Beiträge zur Geologischen Karte der Schweiz, [N.F.] 26, Spezialkarte No. 48.

Simpson, C. (1982). The structure of the northern lobe of the Maggia nappe, Ticino, Switzerland. Eclogae Geologicae Helvetiae, 75, 495-516. 
Spicher, A. (1972, 1980). Tektonische Karte der schweiz, 1:500,000. Basel: Schweizerische Geologische Kommission.

Spring, L., Reymond, B., Masson, H., \& Steck, A. (1992). La nappe du Lebendun entre Alte Kaserne et le Val Cairasca (Massif du Simplon): nouvelles observations et interprétations. Eclogae Geologicae Helvetiae, 85(1), 85-104.

Steck, A. (1968). Die alpidischen Strukturen in den Zentralen Aaregraniten des westlichen Aarmassivs. Eclogae Geologicae Helvetiae, 61, 19-48.

Steck, A. (1980). Deux directions principales de flux synmétamorphique dans les Alpes centrales. Bulletin de la Société Vaudoise de Science naturelle (358), 75, 141-149.

Steck, A. (1984). Structures de déformations tertiaires dans les Alpes centrales (transversale Aar-Simplon-Ossola). Eclogae Geologicae Helvetiae, 77, 55-100.

Steck, A. (1990). Une carte des zones de cisaillement ductile des Alpes centrales. Eclogae Geologicae Helvetiae, 83, 603-627.

Steck, A. (1998). The Maggia cross-fold: an enigmatic structure of the Lower Penninic nappes of the Lepontine Alps. Eclogae Geologicae Helvetiae, 91, 333-343.

Steck, A. (2008). Tectonics of the Simplon massif and Lepontine gneiss dome: deformation structures due to collision between the underthrusting European plate and the Adriatic indenter. Swiss Journal of Geosciences, 101, 515-546.

Steck, A., Bigioggero, B., Dal Piaz, G. V., Escher, A., Martinotti, G. \& Masson, H. (1999). Carte géologique des Alpes de Suisse occidentale, 1 : 100,000, Carte géologique spéciale $N^{\circ} 123$. Berne: Service Hydrologique et Géologique National.

Steck, A., Epard, J. L., Escher, A., Gouffon, Y. \& Masson, H. (2001). Notice explicative de la carte géologique des Alpes de suisse occidentale 1:100000. Carte géologique spéciale $N^{\circ} 123$. Berne: Office fédéral des Eaux et de la Géologie.

Steck, A., Epard, J.-L., Escher, A., Lehner, P., Marchant, R., \& Masson, H. (1997). Geological interpretation of the seismic profiles through Western Switzerland: Rawil (W1), Val d'Anniviers (W2), Mattertal (W3), Zmutt-Zermatt-Findelen (W4) and Val de Bagnes (W5). In O. A. Pfiffner, P. Lehner, P. Heitzmann, S. Mueller, \& A. Steck (Eds.), Deep structure of Swiss Alps: Results of NRP 20 (pp. 241-250). Basel: Birkhäuser.

Steck A., Epard J.L., Escher A., Marchant, R., Masson, H., \& Spring L. (1989). Coupe tectonique horizontale des Alpes centrales. Mémoires de géologie (Lausanne), 5.

Steck, A., \& Hunziker, J. (1994). The tertiary structural and thermal evolution of the Central Alps - compressional and extensional structures in an orogenic belt. Tectonophysics, 238, 229-254.

Steck, A., Ramsay, J. G., Milnes, A. G., \& Burri, M. (1979). Compte rendu de l'excursion de la société Géologique suisse et la société de Minéralogie et Pétrographie en Valais et en Italie nord du 2 au 5 octobre 1978. Eclogae Geologicae Helvetiae, 72(1), 287-311.

Steck, A., \& Tièche, J. C. (1976). Carte géologique de l'antiforme pérdotitique de Finero avec observations sur les phases de deformation et de recristallisation. Schweizerische Mineralogische und Petrographische Mitteilungen, 56, 501-512.
Stern, W. B. (1966). Zur Mineralchemie von Glimmern aus tessiner Pegmatiten. Schweizerische Mineralogische und Petrographische Mitteilungen, 46, 137-188.

Streckeisen, A \& Wenk, E., with a contribution by Frey, M. (1974). On steep Isogradic surfaces in the Simplon area. Contribution to Mineralogy and Petrology, 47, 81-95.

Surace, I. R., Clauer, N., Thélin, P., \& Pfeifer, H. R. (2011). Structural analysis, clay mineralogy and $\mathrm{K}-\mathrm{Ar}$ dating of fault gouges from Centovalli Line (Central Alps) for reconstruction of their recent activity. Tectonophysics, 510, 80-93.

Tektonische Karte der schweiz, 1: 500'000 (2005). Federal Office for Water and Geology. Bern.

Trommsdorff, V. (1990). Metamorphism and tectonics of the Central Alps: the Alpine lithospheric mélange of Cima Lunga and Adula. Memorie della Societa Geologica Italia, 45, 39-49.

Trommsdorff, V., \& Nievergelt, P. (1983). The Bregaglia (Bergell): Iorio intrusive and its field relations. Memorie della Societa Geologica Italia, 26, 55-68.

Trümpy, R. (1980). Geology of Switzerland. Basel: Wepf \& co.

Vannay, J.-C., \& Allemann, R. (1990). La zone pièmontaise dans le Haut-Valtournanche Val d'Aoste, Italie. Eclogae Geologicae Helvetiae, 83, 21-39.

Voll, G. (1976). Recrystallization of quartz, biotite and feldspars from Erstfeld to the Leventina nappe, Swiss Alps and its geological sgnificance. Schweizerische Mineralogische und Petrographische Mitteilungen, 56, 641-647.

Walther, P. (1950). Das Ostende des basischen Gesteinszuges IvreaVerbano und die angrenzenden Teile der Tessiner Wurzelzone. Schweizerische Mineralogische und Petrographische Mitteilungen, 30, 1-144.

Wenk, E. (1955). Eine Strukturkarte der Tessineralpen. Schweizerische Mineralogische und Petrographische Mitteilungen, 53, 311-319.

Wenk, E. (1970). Zur regionalmetamorphose und ultrametamorphose im Lepontin. Fortschritte der Mineralogie, 47, 34-51.

Wenk, E., \& Keller, F. (1969). Isograde in Amphibolitserien der Zentralalpen. Schweizerische Mineralogische und Petrographische Mitteilungen, 49, 157-191.

Wieland, H. (1966). Zur Geologie und Petrographie der Valle Isorno (Novara, Italia). Schweizerische Mineralogische und Petrographische Mitteilungen, 46, 189-303.

Wolff, R., Dunkl, I., Kesselbach, G., Wemmer, K., \& Siegesmund, S. (2012). Thermochronological constraints on the multiphase exhumation history of the Ivrea-Verbano Zone of the Southern Alps. Tectonophysics, 579, 104-117.

Zingg, A., Handy, M. R., Hunziker, J. C., \& Schmid, S. M. (1990). Tectonometamorphic history of the Ivrea Zone and its relationship to the crustal evolution of the Southern Alps. Tectonophysics, 182, 169-192.

Zwingmann, H., \& Mancktelow, N. (2004). Timing of Alpine fault gouges. Earth Planetary Science Letters, 223, 415-425. 